\title{
$\underline{\text { Social Security Rules and Marginal Tax Rates }}$
}

Martin Feldstein and Andrew Samwick ${ }^{1}$

The social security payroll tax has become the largest tax paid by the majority of American households. Although the statutory marginal social security tax rate is the same for all those with wage and salary income up to the maximum level, ${ }^{2}$ the complex rules linking social security taxes and subsequent benefits imply that the net marginal social security tax on additional earnings varies substantially among individuals. For some taxpayers, the net marginal social security tax is equal to the statutory rate while for other taxpayers the combined effect of the tax and the resulting benefits implies a very much lower net marginal tax rate or even a negative marginal tax rate when the incremental benefits exceed the additional taxes.

\footnotetext{
${ }^{1}$ Martin Feldstein is Professor of Economics, Harvard University, and President of the National Bureau of Economic Research. Andrew Samwick is a graduate student at the Massachusetts Institute of Technology and a research assistant at the National Bureau of Economic Research.

${ }^{2}$ The social security tax rate is now 11.2 percent, including the payments by both employers and employees but excluding the portion of the social security tax earmarked for the social security health (Medicare) and disability programs. Because Medicare benefits are not related to past earnings, the Medicare component of the payroll tax is a uniform rate over the relevant income range. Although disability benefits are related to earnings histories, the taxes and benefits paid under the disability insurance program are small compared to the retirement portion and are not included in the current analysis. The tax is paid on wage and salary and self-employment incomes up to a maximum level which in 1990 was $\$ 51,300$ and which automatically increases from year to year with the average level of wages. Approximately 94 percent of all workers covered by social security earn less than this maximum level. Workers with incomes above this level pay the maximum total social security tax but face no incremental social security tax on additional income.
} 
The size and heterogeneity of net marginal social security taxes imply that any analysis which involves personal marginal tax rates should explicitly reflect the net marginal social security tax rate. In practice, however, this has not been done. Studies of the effects of the marginal tax rate on individual labor supply incorporate either the statutory marginal payroll tax rate or ignore the payroll tax completely; see for example Hausman (1981 and 1985) and the studies cited in those papers. Similarly, studies of the impact of unemployment insurance on the net cost of unemployment either ignore the payroll tax or do not distinguish between gross and net marginal social security taxes (see, for example, Feldstein (1974 and 1976) and Solon (1985)). There are numerous other research areas, including such different things as tests of the theory of compensating differentials and studies of the demand for fringe benefits, that should include information on net marginal social security taxes. The information presented in the current paper will allow future studies to do so.

The complex rules linking social security taxes and subsequent benefits were not designed to be actuarially fair for each worker. The present actuarial value of the benefits that result from earning an additional dollar of income is higher for older workers than for younger ones. It is also generally higher for female workers than for male workers and relatively higher for individuals with low wage levels than for those with higher wage levels. The analysis presented below shows that despite the uniform statutory payroll tax rate, the actual effect of incremental earnings varies between a marginal tax rate of 11.2 percent and a marginal subsidy rate of at least 35 percent.

We have calculated the net marginal social security tax rate for employees in 72 different income-demographic groups. Within each such income-demographic group, the net marginal social security tax rate depends on the employee's age. Key examples of these relations are given in the 
body of the paper and complete age profiles for all 72 income-demographic groups are available from the authors and published in the appendix to Feldstein and Samwick (1992).

Previous studies by Gordon (1983), Browning (1985), and Burkhauser and Turner (1985) have recognized the link between the marginal statutory tax rate and the marginal benefit entitlements inherent in the social security system and developed theoretical frameworks with which to analyze the issue. The also made calculations of the net tax rates similar to ours for a few cohorts of the population to show the extent to which the net marginal tax rate differs from the statutory rate in the startup and mature phases of the social security program. The purpose of our analysis is to demonstrate the wide variation in tax rates among different groups within the population. In addition to presenting a more general algorithm for computing the net tax rates, we incorporate genderspecific mortality rates, survivor's benefits, delayed retirement credits, and the personal income tax rates into our calculations. This increased detail enables us to address issues of efficiency and equity beyond the scope of these other studies.

Section one of the paper reviews the social security rules that affect the net present value of benefits that result when an additional dollar of income is earned. Section two describes the calculation of the net marginal social security tax rate. In section three we present and discuss selected marginal tax rates that illustrate their dependence on age, income and demographic characteristics. The fourth section comments on some of the possible distorting effects of these differences in net marginal social security tax rates. There is a very brief concluding section.

\section{Social Security Tax and Benefit Rules}


The social security tax is a proportional tax on wage and salary income (and self-employment income) up to a maximum level. In 1990, the year represented by our calculations, the social security tax rate was 11.2 percent and this was levied on incomes up to $\$ 51,300$. The 11.2 percent rate excludes the portions of the payroll tax that are earmarked for disability insurance and for Medicare. Half of this tax is technically paid by the employer and half by the employee. Since the incidence of the tax does not depend on this distinction, we make our calculations as if the tax were paid entirely by the employee. ${ }^{3}$

The social security tax is based on the gross wage received by the employee and is not deductible in calculating the wage that is subject to the federal personal income tax (although some states do allow some part of it to be deducted for state income tax calculations). Thus, an employee in the 15 percent federal income tax bracket who earns an additional dollar of gross wages will pay 20.6 cents of additional tax and his employer will pay an additional 5.6 cents of tax for a combined tax of 26.2 cents. Note that the employer's portion of the tax is not included in the taxable income of the employee. The employee with an incremental dollar of wages receives net disposable income of 79.4 cents while the total cost to the employer is $\$ 1.056$, the one dollar of wages plus the 5.6 cents of social security tax. The tax rate as a percentage of the gross cost of employment is thus 24.8 percent $(26.2 / 105.6=0.248)$. Since tax rates are generally stated relative to pretax wages, we follow that convention in this paper. In some applications, it would be appropriate to take into account the reduction in the personal income tax as a fraction of the gross cost of employment that occurs

${ }^{3}$ Our description of the social security rules and provisions is derived from Social Security Administration (1990). Detlefs and Myers (1990) also provides a good description. 
because the employer's payroll tax payment is subtracted in defining the wage subject to the personal income tax.

The benefit that an individual is eligible to receive at retirement does not depend primarily on the taxes that he and his employer have paid but on a measure of the average wage income of the employee during his working life. Since tax rates have varied substantially over time, two individuals with the same average wage can have paid substantially different amounts of tax, implying a significant degree of "horizontal inequity" (Musgrave, 1959) in the social security program. At any time, however, there is an unambiguous relation between an additional dollar of payroll tax paid and the incremental amount of future benefits to which the individual will be entitled.

The measure of an individual's average lifetime income on which his or her benefits are based is known as the Average Indexed Monthly Earnings (AIME). Although the measure is given as dollars per month, all months of earnings within a given year are treated identically, so we will discuss the AIME to be a weighted average of yearly income (divided by twelve, of course) without loss of generality. There are three main features of the AIME calculation.

First, in order for a worker to be entitled to any benefits at all, his earnings history must qualify him as "Fully Insured." Every year the employee works in "covered employment"" entitles him to "Quarters of Coverage," one for every $\$ 520$ in annual income up to four per year. (This dollar amount is for 1990 and is subject to an automatic increase each year). Most employees will earn four

${ }^{4}$ Employment is "covered" if the employer and employee are required to pay the Social Security payroll tax. This includes essentially all employees except some government workers. Note that only earnings up to the maximum taxable level are considered "covered earnings." 
each year, but some very low wage or part-time workers may earn fewer. The number of Quarters of Coverage required is equal to forty for all workers born in or after 1929; those born before that need one less quarter for each year before 1929 they were born. Thus, most people will become Fully Insured after only ten years of work. On the other hand, those workers with very low average earnings may take forty years to accumulate the required quarters. For the purposes of this paper, we assume that each worker is Fully Insured.

Second, the number of years of earnings that are actually included in the average must be determined. As in the case of determining whether an employee is Fully Insured, the rules governing the number of years in the average are based on the years when an employee is 21 through 60 , inclusive, with a provision that years before 1950 are not required to count in the total. All employees have the option to drop up to five of their lowest years of earnings. This option exists to ensure that employees do not have their AIME reduced due to declining earnings as they near retirement, spells of unemployment they may have suffered during their prime earning years, or years spent away from the labor force raising children. This number is therefore thirty-five for employees born in or after 1929 and declines by one for each year before 1929 in which the employee was born. For example, someone born in 1923 would include his best twenty-nine years of earnings. In the analysis of the next sections, we implicitly assume that the year in which the additional earnings occur is one that will actually be counted in the AIME when the employee begins collecting benefits.

Third, the earnings are indexed to the growth in the national average annual wage. Every year of earnings prior to age 60 is revalued so that it represents the same share of the average annual wage in the year in which the employee turns 60 as it did in the year in which it was earned. An individual whose monthly earnings are always equal to the national average and who works through 
age 60 will have an AIME at age 62 equal to the national average earnings in the year he turned 60. An individual whose monthly earnings are always 50 percent of the national average and who works through age 60 will have an AIME at age 62 equal to 50 percent of the national average earnings in the year he turned 60 . When an individual continues to work after age 60 , the additional months of nominal earnings are included without indexing, and no further adjustment is made to the earnings before age 60 to reflect the rise in wages after the individual has reached age 60 . This procedure, which has the effect of reducing the credit toward subsequent benefits of earnings before age 60 , is one of those political compromises that limits program costs but that otherwise defies logical explanation.

Thus at age 65 the AIME of an individual $i$ who has just retired is:

$$
A I M E_{i T}=(1 / 35)(1 / 12)\left(\sum_{t \in B} \frac{w_{* T}}{w_{* t}} w_{i t}+\sum_{t \in A} w_{i t}\right)
$$

where $\mathrm{w}_{\mathrm{it}}$ is the earnings of individual $\mathrm{i}$ in year $\mathrm{t}, \mathrm{w}_{*_{\mathrm{t}}}$ is the average covered earnings of all employees in that year, and $\mathrm{T}$ denotes the year in which the individual reached age 60 . The average is calculated over the best 35 years of earnings and divided by 12 to convert from yearly earnings to a monthly average. B denotes the set of all years through age 60 that will be counted among the 35 best, and A denotes the set of all such years that occur after the individual turns 60 .

The monthly benefit to which a retired worker is entitled at the time of retirement, known as the Primary Insurance Amount or PIA, is a function of the individual's AIME; this relation is described below. After retirement the monthly benefit is automatically increased each year in proportion to the consumer price index. Retired workers with a dependent spouse receive a monthly 
benefit equal to 150 percent of the amount that would be paid to an individual retiree, and a surviving spouse of a retired worker receives a benefit equal to the monthly benefit of the deceased worker.

The function relating the PIA to the AIME has three segments with sharply declining ratios of PIA to AIME. In 1990, the first \$356 of AIME (equivalent to average indexed earnings of $\$ 4,272$ per year) entitled the retiree to a primary insurance amount equal to 90 cents per dollar of AIME. In the next segment of the PIA schedule, covering AIME values up to $\$ 2,145$ in 1990 (equivalent to average indexed earnings of $\$ 25,740$ ), each dollar of AIME entitled the retiree to 32 cents of primary insurance benefits. Above that level, each dollar of AIME produced only 15 cents of primary insurance benefits. The three percentages remain the same from year to year but the "bendpoints" that divide the three segments are indexed annually for the rise in the average level of covered earnings.

This PIA function is very redistributive, giving a much higher ratio of benefits to previous income (and therefore generally to previous tax contributions) for retirees with a history of low wages than for retirees whose preretirement wages had been higher. A retiree with average annual indexed earnings of $\$ 10,000$ would receive a primary insurance amount of $\$ 5,678$, replacing 57 percent of preretirement income. Doubling the individual's average preretirement income to $\$ 20,000$ would increase the PIA to $\$ 8,878$ a year for a 44 percent replacement rate. In contrast, an individual with $\$ 40,000$ average indexed earnings would receive benefits of $\$ 12,854$ for a 32 percent replacement rate. $^{5}$

\footnotetext{
${ }^{5} \mathrm{~A}$ retiree with a dependent spouse would have a replacement rate equal to 1.5 times that of an individual retiree, implying replacement rates of 48 percent for someone with $\$ 40,000$ of average preretirement earnings, 67 percent with $\$ 20,000$ of earnings and 85 percent for
} 
Two additional social security rules reduce the net benefits of some individuals over age 65 . First, the full amount of benefits is paid only to individuals whose current wage and salary earnings are low enough to classify them as retired. In 1990 , an individual had to earn less than $\$ 9,360$ to qualify for full benefits. Each three dollars of earnings above that amount caused benefits to be reduced by one dollar. This benefit reduction is applied only to workers less than 70 years old; after age 70, benefits are not affected by the individual's current labor earnings. Moreover, for each month beyond age 65 that the individual does not claim benefits, the future benefits are increased by an amount that, when the adjustment is fully phased in, will more nearly approximate an actuarially fair adjustment for the reduced period for which benefits will be paid. ${ }^{6}$

Net social security benefits are also reduced for higher income retirees by a rule that includes one-half of social security benefits in taxable income if total adjusted gross income plus one-half of social security benefits exceeds $\$ 25,000$ for an individual income taxpayer or $\$ 32,000$ for married couples who file their tax returns jointly. For an individual who was in the 28 percent marginal tax bracket in 1990, this rule had the effect of reducing net social security benefits by 14 percent, thereby reducing the replacement rate from 32 percent to 28 percent for the worker described above. ${ }^{7}$

someone who had had $\$ 10,000$ of earnings.

${ }^{6}$ The credit for delayed retirement will rise from 3.5 percent per year of delay for those born in 1925 to 8.0 percent for those born in 1943 and later. The extent to which even those in the youngest age group may still not receive a full actuarial adjustment for delayed retirement is discussed below.

${ }^{7}$ The $\$ 25,000$ and $\$ 32,000$ tax thresholds are not indexed for inflation or for the rise in wage incomes. The amount of benefits included in adjusted gross income is phased in by including the lesser of one-half of benefits and one-half of the excess of benefits plus AGI over the base amount of $\$ 25,000$ or $\$ 32,000$. 


\section{The Net Marginal Social Security Tax Rate}

The social security net marginal tax is the difference between the social security tax of 11.2 cents per dollar of earnings and the present value of the net benefits to which an additional dollar of earnings entitles the individual. Thus, if an additional dollar of earnings entitles the individual to additional benefits with a present value of 5.0 cents, the net social security marginal tax rate is 6.2 percent.

This section discusses the assumptions that we have made to calculate the present value of the additional benefits that result from an additional dollar of earnings for individuals of different age, sex, dependency and income groups.

The present value of the incremental benefits to which an individual becomes entitled by earning an additional dollar depends on the employee's age and on four primary demographic or economic factors:

(1) the sex of the employee since mortality rates depend on sex as well as age;

(2) whether the retiree will claim benefits for himself or herself as an individual or will claim benefits with a dependent spouse;

(3) the segment of the AIME schedule which determines whether the PIA is credited at 90 cents for an incremental dollar of AIME, 32 cents or only 15 cents; and

(4) the personal income tax bracket at which social security income will be taxed during retirement.

We analyze and present (in the appendix to Samwick and Feldstein (1992)) net marginal tax rates for 36 possible economic-demographic combinations for each individual age: three sex/dependency groups (male workers who will claim benefits only for themselves; male workers 
who will claim benefits for themselves and a dependent spouse; and female workers who will claim benefits for themselves), ${ }^{8}$ three segments of the PIA-AIME schedule, and four possible marginal tax rates.

Although individuals who reach age 70 begin receiving benefits regardless of their earnings at that time, benefits may be reduced or eliminated for individuals between their normal retirement age $^{9}$ and 70 on the basis of the individual's earnings. An individual who is eligible for partial benefits (because his or her earnings exceed the maximum earnings for full benefits by less than three times the benefit to which he or she is otherwise entitled) may choose to forego all benefits in order to qualify for the delayed retirement credit. We therefore examine two representative types of individuals; those who begin full benefits at their normal retirement age and those who wait until 70 to receive full benefits. ${ }^{10}$

${ }^{8}$ It is now more common than in the past for married women to claim benefits in their own right than on the basis of their husbands earnings. A woman will receive higher benefits in her own right if the benefits to which she is entitled exceed 50 percent of those payable to her husband. After her husband's death, however, she will receive more as a "surviving spouse" unless her own level of benefits actually exceeded that of her husband. Although the full calculations for "nondependent" spouses are not explicitly discussed in the analysis, some examples will be given to highlight the differences between the tax rates for this group and other groups.

${ }^{9}$ Normal retirement age is now 65 and will rise in the future to 67 . Previously, we have been using 65 as a typical person's normal retirement age for illustrative purposes.

${ }^{10}$ Another representative group would be those who retire as soon as possible, age 62 with reduced benefits for all workers who are Fully Insured. The comparison of the tax rates affecting workers planning to retire at 62 and those planning to retire at the normal retirement age is not generally different from the comparison between the latter group and those retiring at 70 . Therefore, the tax rates affecting the group retiring at 62 will be mentioned only briefly in this context in the next section. 
Our analysis simplifies the social security program in a number of ways. We ignore the possibilities of divorce and remarriage as well as the availability of benefits for dependent children of young widows or widowers. All dependent spouses are assumed to be two years younger than the primary employee.

Since all of the features of the social security program are indexed to either the consumer price index or the average level of wages ${ }^{11}$ there is no need to project inflation or any nominal magnitudes. The only relevant parameters are the rate of increase of the average real wage and the real discount rate. Our central calculations assume that real wages in covered employment will rise at one percent a year ${ }^{12}$ and that the real discount rate is 2.0 percent. $^{13}$

A specific example will show our method of calculation. Consider a single woman who is now aged 45 and plans to start collecting social security benefits when she reaches the normal retirement age (66 in the year 2011) based on her own earnings record. Her current annual wage income is $\$ 20,000$ and she expects no change in her wage income relative to the average wage in the economy. She also expects that after she reaches age 66 her total income (including wages, pension

\footnotetext{
${ }^{11}$ The one exception is the level of total income at which social security benefits become subject to tax and this is dealt with explicitly in our analysis by specifying alternative rates of tax on social security benefits.

${ }^{12}$ The average wage rate in covered employment has increased at an average rate of 1.01 percent since 1951.

${ }^{13}$ The real discount rate should correspond to the riskless after-tax real return that individuals can get on long-term savings. With a long-term government bond interest rate of 8 percent and an inflation rate of four percent, an individual with a 25 percent marginal tax rate receives a real after tax rate of return of two percent.
} 
income and income from savings) will exceed $\$ 25,000$, subjecting her social security benefits to taxation at a 15 percent federal income tax rate. ${ }^{14}$

Since she was born in 1945, the social security law provides that her AIME at age 66 will be based on 35 years of earnings as described above. An additional dollar earned in 1990 raises her current monthly average earnings by $\$(1 / 12)$ and the AIME by $\$(1 / 12)(1 / 35) \mathrm{W}_{*_{\mathrm{T}}} / \mathrm{W}_{*_{\mathrm{t}}}$ where $\mathrm{W}_{*_{\mathrm{T}}}$ is the average earnings in covered employment in 2005 when she reaches 60 and $\mathrm{w}_{*_{\mathrm{t}}}$ is the average earnings in 1990 when she is 45 . If the average real wage rises at 1.0 percent per year, $\mathrm{W}_{*_{\mathrm{T}}} / \mathrm{W}_{*_{\mathrm{t}}}=1.16$ and the additional dollar of earnings in 1990 raises the AIME by $\$(1 / 12)(1 / 35) 1.16=\$ 0.00276$.

Because the employee expects that her own earnings will rise at the same rate as the average level of earnings, her current $\$ 20,000$ a year wage income implies that her future level of AIME will be such that each additional dollar of AIME will increase her primary insurance amount by 32 cents. ${ }^{15}$ This important ratio is not very sensitive to relative movements in her income; the marginal replacement ratio of PIA to AIME would remain 32 percent even if her relative AIME rose by 25 percent or fell by more than 50 percent. The incremental dollar of wage income at age 45 would therefore raise her PIA by $(0.32)(\$ 0.00276)=\$ 0.00088$ and her annual benefit at age 66 by $12 \mathrm{x}$ $\$ 0.00088=\$ 0.01061$. Indexing post-retirement benefits to the consumer price index maintains the real value of this benefit during her retirement. Since half of this benefit will be subject to federal

\footnotetext{
${ }^{14}$ Recall that the $\$ 25,000$ threshold is not indexed. With a four percent inflation rate, that corresponds to less than $\$ 11,000$ at 1990 prices.

${ }^{15}$ Although her real income will rise over time, since the bendpoints of the AIME-PIA schedule are increased in proportion to national average earnings in covered employment she will remain in the 32 percent marginal replacement segment implied by her current $\$ 20,000$ annual wage income. We are implicitly assuming that past wages were not so different from current wages as to make current earnings a poor approximation for lifetime real earnings.
} 
income tax at a 15 percent rate, the net incremental annual benefit will be $(1-.075) \times \$ 0.01061=$ $\$ 0.00982$.

The present actuarial value as of age 45 of this incremental annual benefit beginning at age 66 would be:

$$
P A V B_{45}=\$ 0.00982 \sum_{n=66}^{N} P(n \mid 45)(1+r)^{45-n}
$$

where $P(n \mid 45)$ is the probability that a female aged 45 will survive to age $n, N$ is the age by which she will be dead for certain (we use 110), and $\mathrm{r}$ is the real discount rate. Using the current life tables for 1990 from Faber (1982) to estimate these survival probabilities and a real discount rate of 2 percent implies that for this individual $\mathrm{PAVB}_{45}=0.0884$. Thus, an additional dollar of earnings at age 45 entitles the employee to incremental benefits with a present actuarial value at age 45 of $\$ 0.0884$. The net marginal social security tax rate of the 45 year old woman in our example is thus $0.112-0.0884=0.0236$. Comparing the gross social security tax rate of 11.2 percent with the net social security tax rate of 2.4 percent shows that the benefits offset 79 percent of the marginal tax in the current example.

If this employee expected not to claim benefits before age 70 , her benefit calculation would be altered by increasing the AIME for the wages earned between 66 and 70 and raising the PIA at age 70 by 32 percent to reflect the credit available for delayed retirement. The effect of an incremental dollar of earnings on the AIME would be exactly the same, since the number of years of earnings in the average does not depend on the number of years actually worked. If high enough, the additional years of earnings between 66 and 70 will simply substitute for earlier years of lower income. The increment to the AIME as of age 70 of an extra dollar earned at age 45 would therefore 
be $\$ 0.00276$, implying an increased PIA of $\$ 0.000884$, as before. The delayed retirement credit would raise the initial benefit by 32 percent (four years delay times 8 percent per year) to $\$ 0.001167$ a month or $\$ 0.014000$ a year. After subtracting the personal income tax on half of this benefit the additional real benefit starting at age 70 would be $\$ 0.0129$ per year. The present actuarial value of this increment as of age 45 would be $\$ 0.0884$, which turns out to be essentially the same as if she would have retired at age 66 .

Note, however, that her overall benefits will increase as a result of working the extra years if any of them are counted in her best 35 years. This does not affect the marginal tax on earnings at 45 unless the earnings from age 45 are no longer counted in the average (in which case the marginal tax rate at age 45 is the full statutory rate of 11.2) or the earnings are high enough to push her past a bendpoint, making the marginal conversion of AIME to PIA 15 percent rather than 32 percent. This example illustrates that the full adjustment of 8 percent per year is roughly actuarially fair for a typical female worker. The fact that men have higher mortality risk at all ages than women, however, implies that even a delayed retirement credit of 8 percent will generally not be enough to equilibrate the marginal tax rates for male employees for waiting until age 70, a point to which we will return in the next section.

Before examining the sensitivity of the net marginal social security tax to differences in age and other factors, we review briefly the method of calculating the present actuarial value of benefits for a married employee with a nonworking spouse (or, equivalently, a spouse whose earnings are so low relative to her husband that she will receive benefits as a spouse rather than on the basis of her own earnings record). The general benefit rules are as follows: The spouse benefit raises the amount received by 50 percent during every year that the man and his wife are both alive. If only one of 
them is alive, the benefit is equal to what the retiree himself would have received; i.e., the surviving dependent typically receives a benefit equal to 100 percent of the benefit to which the deceased worker would have been entitled. ${ }^{16}$

The calculation of actual benefits is complicated by the possibility that the worker might die very early in his working life. When this occurs, the number of years required for Fully Insured status and the number that must be included in the average are adjusted accordingly. The number of Quarters of Coverage required for Fully Insured status is the number of years after 1950 (or the year the worker turns 21, if later) through the year before death occurs (or the year the worker turns 61, if earlier). The number must be at least six. ${ }^{17}$ As in the case of retirement benefits, the number

\footnotetext{
${ }^{16}$ Technically, these two statements apply only to spouses or widows who have reached their normal retirement ages. For the spousal benefit, a reduction of $25 / 36$ percentage points is made for the first 36 months before her normal retirement age in which the spouse collects benefits, or 8.33 percent per year. The reduction factor for up to 24 additional months (when the time between 62, the first age at which reduced benefits can be taken, and the normal retirement age exceeds 3 years) is an additional $5 / 12$ percent per month or 5 percent per year. Similarly, widow's benefits are first available at age 60. If they are first received between 60 and her normal retirement age, they are reduced at a rate of 28.5/n percent per year, where $\mathrm{n}$ is the number of years between age 60 and the normal retirement age.

For our calculations, we make the behavioral assumptions that maximize the PAVB. Regarding spousal benefits, the total present actuarial value of benefits (PAVB) is 1 percent higher for younger workers and 3.5 percent higher for older workers if the spousal benefits are taken at the normal retirement age instead of the year in which the retiree first begins taking benefits. For the widow's benefits, the total PAVB is 3.5 percent to 5.5 percent higher when the widow takes them as soon as possible (age 60 or the year the husband dies, whichever is later) than when she waits for her normal retirement age. Thus, we assume spousal benefits begin at the normal retirement age and widow's benefits begin as soon after the husband dies as the law allows.

${ }^{17}$ There is also an insured status known as Currently Insured, which requires only that six Quarters of Coverage were earned in the 13 calendar quarters ending with the quarter in which death occurs. The benefits payable in this case are a lump-sum death benefit which is independent of earnings and monthly benefits that require the presence of children in the household. Since we are dealing with a marginal increase in earnings and we do not consider benefits for surviving children, this insured status is not relevant to our analysis.
} 
of years of earnings needed is five less than the number of Quarters of Coverage needed. The number of years cannot be less than two. Neither of these numbers will ever exceed their values when computed for retirement benefits. Note that this implies that a given year of earnings may represent more than 1/35 (the figure for retirement benefits) of the number of years used, resulting in much higher marginal effects on benefits in the rare event of an early death. The indexing of earnings is also slightly adjusted in the event of an early death. The year to which benefits are indexed is either the second year before death or the second year before the spouse is first eligible to receive benefits, whichever is more advantageous. Since our couples all have the wife two years younger, the second strategy will generally dominate the first.

The basic formula for calculating the present value of the benefits of a worker at age $a$ with a dependent spouse who plans to retire at the normal retirement age can be written as the sum of three terms:

$$
\begin{aligned}
\text { TBEN } & =\sum_{k=a}^{N}\left[P_{1}(k \mid a)-P_{1}(k+1 \mid a)\right] P I A_{d}(k, w) \sum_{s=\max (k, 62)}^{N+2} P_{2}(s-2 \mid a-2)(1+r)^{c} \\
& +\sum_{s=66}^{N} P_{1}(s \mid a) P I A_{r}(66, w)(1+r)^{a-s} \\
& \left.+\sum_{s=66}^{N} 0.5 I(s-2 \geq 66) P_{1}(s \mid a) P_{2}(s-2 \mid a-2)\right] P I A_{r}(66, w)(1+r)^{a-s}
\end{aligned}
$$

The first term refers to the expected value of widow's benefits conditional on the worker dying at any age $\mathrm{k}$. If $\mathrm{P}_{1}(\mathrm{k} \mid \mathrm{a})$ is the probability that a male age a survives to age $\mathrm{k}$, the probability that a man age a will die at age $\mathrm{k}$ is $\mathrm{P}_{1}(\mathrm{k} \mid \mathrm{a})-\mathrm{P}_{1}(\mathrm{k}+1 \mid \mathrm{a})$. We denote the effect on the PIA of an additional dollar of earnings of an individual who earns $\mathrm{w}$ in the current year and dies at age $\mathrm{k}$ by PIA $_{d}(k, w)$. As described above, the number of Quarters of Coverage for Fully Insured status and the 
number of years of earnings counted in the AIME are reduced for workers who die before they could have retired. Note that if $\mathrm{k}$ is not less than the normal retirement age of 66 , then PIA $_{d}(k, w)$ will simply be the PIA that the employee had while retired, which we will denote PIA $_{r}(66, w)$. The probability that the spouse is alive at age s to collect the benefit is $\mathrm{P}_{2}(\mathrm{~s}-2 \mid \mathrm{a}-2)$, where the subscript 2 on the probability refers to a female survival table and the subtraction of 2 is the result of the assumption that she is two years younger than he. Note that for each possible year of death $\mathrm{k}$, the spouse begins collecting as soon as possible, the year the husband died or the year he would have been 62 if he dies before that year. The benefit paid when she is s-2 is discounted to the present when she is a-2 years old by the factor $(1+r)^{a-s}$.

The second term refers to the expected value of the husband's retirement benefits conditional on reaching his normal retirement age of 66 . In this case, his benefits will be based on $\mathrm{PIA}_{\mathrm{r}}(66, \mathrm{w})$ as described above. This PIA is discounted for mortality by $\mathrm{P}_{1}\left(\mathrm{~s} \mid\right.$ a) and for interest by $(1+\mathrm{r})^{\mathrm{a}-\mathrm{s}}$.

The final term refers to the expected value of the dependent spouse's benefits conditional on them both reaching age 66 to collect them. Since this benefit is just half that of the retired worker, the yearly benefit for the husband's retirement can be multiplied by $\mathrm{P}_{2}(\mathrm{~s}-2 \mid \mathrm{a}-2)$, to discount for her mortality; 0.5 , to reflect the percentage of his benefit to which she is entitled; and I(s-2 $\geq 66)$, which is an indicator function that is 1 during all benefit years in which she has attained her normal retirement age of 66 and 0 otherwise. Recall that we have assumed that she waits until 66 to avoid an early retirement reduction on her spousal benefits.

To illustrate this calculation we consider a 45 year old man with a 43 year old wife. To make this case as similar as possible to the case of the woman examined above, assume that he earns 
$\$ 20,000$ a year, that he expects his relative wage to remain unchanged, and that he expects that upon retirement at age 66 his benefit will be subject to federal income tax at a 15 percent rate.

Looking at the first term of equation 3 , the probability that he will die by age 46 is 1 $\mathrm{P}_{1}(46 \mid 45)=0.0040$. If he dies at age 46, an additional dollar of earnings in 1990 raises his AIME by $\$(1 / 12)(1 / 19) \mathrm{W}_{*_{\mathrm{T}}} / \mathrm{W}_{*_{\mathrm{t}}}$ where $\mathrm{W}_{*_{\mathrm{T}}}$ is the average earnings in covered employment in 2005 when he would have reached 60 and $\mathrm{w}_{*_{\mathrm{t}}}$ is the average earnings in 1990 when he is 45 . This is exactly the same formula as that of the single woman in the previous example, except that now the current year is only one of nineteen (45-21-5=19) instead of one of thirty-five because of his death at age 46 . This implies that an additional dollar of earnings raises the AIME by $(1 / 12)(1 / 19)(1.16)=\$ 0.00509$. The additional dollar of wage income at age 45 therefore raises his monthly PIA by $\$ 0.00163$ and his yearly PIA by $\$ 0.01955$. Since half of this benefit will be subject to the federal income tax at a 15 percent rate, the net incremental annual benefit will be $\$ 0.01808$. The discounted sum of the survival probabilities for the dependent spouse is represented by $\Sigma_{\mathrm{s}} \mathrm{P}_{2}(\mathrm{~s}-2 \mid 43)(1+\mathrm{r})^{\mathrm{a}-\mathrm{s}}=12.3186$. Combining these terms implies that the component of the expected benefit conditional on the worker dying at age 46 is $\$ 0.2228$ and, multiplying this by the probability of dying in the 46th year of life, $1-P_{1}(46 \mid 45)$, gives the increment to the expected net benefit associated with the individual earning an additional dollar at age 45 and dying during that year, $\$ 0.00089$. Aggregating over all of the possible years of death gives the value of the first term (net of income tax): $\$ 0.0521$.

The second term is quite straightforward. It is exactly the same as the computation done for the woman in the previous example, except that now the mortality risk is for a man instead of a woman. Repeating those calculations yields a figure of $\$ 0.0622$ after income taxes, which is 
substantially less (roughly $30 \%$ ) than the benefits of $\$ 0.0884$ for the single woman studied above because of the greater male mortality rate.

Finally, there is the third term which measures the present value of the benefits paid to a dependent spouse while her husband is still alive. This number should be less than half the second term, owing to the mortality risk of the wife. For the 43 year old wife of the 45 year old worker, this term is $\$ 0.0190$ after income taxes.

Combining these three terms implies that the actuarial present value of the benefits that the household receives as a result of an additional dollar of wages at age 45 is $\$ 0.1333$. The value of the incremental benefits thus actually exceeds the marginal social security tax rate of 0.112 . The net marginal social security tax rate for the married man with a dependent spouse in this example is thus a negative 0.0213 . At the margin, the effect of the social security program is to offset part of the individual's personal income tax rate. It is interesting to note that the present actuarial value of the retirement benefits paid to the worker himself, $\$ 0.0622$, is actually slightly smaller than the present actuarial benefits paid to the worker's spouse, $\$ 0.0711$. The division of the present actuarial value of the benefits is $47 \%$ in retirement benefits, $14 \%$ in dependent spouse benefits and $39 \%$ in surviving spouse benefits.

This breakdown of benefits according to which spouse must be alive to collect them gives some insight on the marginal tax rates of an important cohort that we have not explicitly treated; namely, two-earner couples. Even if both spouses work and claim retirement benefits as individuals, it is generally the case that one spouse will have a lower benefit than the other. The spouse with lower earnings is subsequently entitled to the PIA of the spouse with higher earnings if the latter dies first. Households in which the PIA of the secondary earner is between 50 and 100 percent of the PIA 
of the primary earner fit this description. In this case, the marginal benefits of the individual with the higher earnings (typically the man) are increased by their effect on the benefits of the spouse while the marginal benefits of the spouse are reduced by the limited period of time during which she will collect benefits on the basis of her own earnings.

Since the shares computed above show that only about 15 percent of the benefits of a male with a dependent spouse are paid to the spouse while he is alive, the present actuarial value of the benefits (PAVB) of a male worker with a nondependent spouse is 85 percent of the PAVB of a male with a dependent spouse. In this example, the 45 year old man with a nondependent spouse will have a net marginal tax rate of -0.23 percent (compared to 4.98 percent for a single man and to -2.13 percent with a dependent spouse). The net marginal tax rate of a 45 year old woman like the one in the first example except that she is married and will collect survivor benefits based on her husband's earnings is 7.20 percent, which is almost 5 percentage points higher than the 2.36 percent for the single woman. Thus, the conclusions we make regarding the tax rates of one-earner couples will also apply generally to the husband in a two-earner couple if he is the primary earner. We can also conclude that the tax rate of a female, nondependent spouse will generally be much higher than the rate on a single woman.

\section{The Effects of Age, Income and Demographic Status on Marginal Social Security Tax Rates}

The evidence presented in this section shows that marginal social security tax rates vary substantially by the age, income, sex and marital status of the employee. Younger workers face much higher marginal tax rates than older workers. Women workers who expect to collect benefits on the basis of their own earnings histories have lower marginal tax rates than men of the same age 
and income and very much less than women who expect to receive benefits on the basis of their husbands' earnings. For some employees the net marginal social security tax rate is not very different from the statutory 11.2 percent gross rate while for others it is very much lower. Married men who expect benefits for dependent and/or surviving spouses may face negative marginal tax rates during much of their working life. Individuals with low average indexed monthly earnings can face extremely high negative marginal social security tax rates, high enough that they can actually make the combined marginal social security and personal income tax rate negative.

Table 1 presents marginal social security tax rates for employees at selected ages from 25 through 60 for discount rates of 2, 4, and 6 percent. The calculations will generally be sensitive to the choice of discount rate because the benefits accrued from earnings during the work life are paid out in the future, sometimes more than fifty years after the income is earned. The calculations are done for employees who can expect that their marginal PIA-to-AIME ratio will be 0.32 ; this is the group which in 1990 had average indexed annual earnings between $\$ 4,272$ and $\$ 25,740$, amounts that rise in proportion to average earnings in covered employment. We describe these as "middle income employees" and assume that when retired 50 percent of their benefits will be subject to a 15 percent personal income tax rate.

Separate calculations are presented for male and female employees who expect that their earnings will be the basis for their own future benefits but not for the benefits of a dependent spouse or surviving spouse. These are described as "Male without Social Security Dependent Spouse" and "Female without Social Security Dependent Spouse." The calculations can apply to both single and married employees, but we will often refer to them as "single" men and women. Two further groups are presented: male employees who expect that their earnings will be the basis for benefits for 
dependent and surviving spouses ("Male with Dependent Spouse") and female employees who expect to receive benefits on the basis of their husbands' earnings as dependent and surviving spouses rather than on the basis of their own earnings ("Female Dependent Spouse"). ${ }^{18}$

The calculations assume that the employees expect to retire at the normal retirement age, currently 65 years and scheduled to rise to 67 years for individuals who are currently 30 years old or younger. Comparisons with the strategy of not retiring before age 70 in order to obtain the full delayed retirement credit and perhaps to continue working without having benefits reduced by the earnings test are presented below.

\footnotetext{
${ }^{18}$ The additional possibility of a female employee with a dependent spouse is sufficiently uncommon in practice that we have not presented calculations. Also note that the "Female Dependent Spouse" can also apply to a male dependent spouse or to any worker whose current annual earnings will not enter into the AIME calculation.
} 
Table 1
Social Security Marginal Tax Rates
of Middle Income Employees
by Discount Rate

\begin{tabular}{|c|c|c|c|c|}
\hline $\begin{array}{c}\text { Discount } \\
\text { rate and } \\
\text { Age in } 1990\end{array}$ & $\begin{array}{c}\text { Male without } \\
\text { Social Security } \\
\text { Dependent Spouse }\end{array}$ & $\begin{array}{c}\text { Female without } \\
\text { Social Security } \\
\text { Dependent Spouse }\end{array}$ & $\begin{array}{l}\text { Male with } \\
\text { Dependent } \\
\text { Spouse } \\
\end{array}$ & $\begin{array}{c}\text { Female De- } \\
\text { pendent } \\
\text { Spouse }\end{array}$ \\
\hline \multicolumn{5}{|c|}{ Discount rate $=.02$} \\
\hline 25 & 6.70 & 4.53 & -0.27 & 11.2 \\
\hline 35 & 5.78 & 3.38 & -0.77 & 11.2 \\
\hline 45 & 4.98 & 2.36 & -2.13 & 11.2 \\
\hline 55 & 3.25 & 0.43 & -4.66 & 11.2 \\
\hline 60 & 2.32 & -0.51 & -5.97 & 11.2 \\
\hline \multicolumn{5}{|c|}{ Discount rate $=.04$} \\
\hline 25 & 9.48 & 8.73 & 6.91 & 11.2 \\
\hline 35 & 8.66 & 7.64 & 5.76 & 11.2 \\
\hline 45 & 7.65 & 6.31 & 3.83 & 11.2 \\
\hline 55 & 5.60 & 3.86 & 0.46 & 11.2 \\
\hline 60 & 4.31 & 2.41 & -1.59 & 11.2 \\
\hline \multicolumn{5}{|c|}{ Discount rate $=.06$} \\
\hline 25 & 10.52 & 10.25 & 9.53 & 11.2 \\
\hline 35 & 9.97 & 9.53 & 8.63 & 11.2 \\
\hline 45 & 9.12 & 8.41 & 6.99 & 11.2 \\
\hline 55 & 7.17 & 6.06 & 3.72 & 11.2 \\
\hline 60 & 5.74 & 4.42 & 1.43 & 11.2 \\
\hline
\end{tabular}

"Middle Income Employees" expect a marginal PIA-to-AIME ratio of 0.32 and a personal income tax rate of 0.15 on half of benefits. Calculations assume "normal age" retirement (currently 65 and scheduled to rise to 67). 
Focusing on the top panel of Table 1, which presents the tax rates assuming a discount rate of 2 percent, note that the net marginal tax rates are very much lower than the 11.2 percent statutory rate for all employees except the "Female Dependent Spouse" category since those workers do not expect to receive any benefit in exchange for the taxes that they are currently paying. Thus, these middle income male employees at age 25 face a net social security marginal tax rate of 6.70 percent; expected future benefits offset 40 percent of the 11.2 percent statutory rate.

The net marginal tax rates decline sharply with age in each category. ${ }^{19}$ Indeed, since all AIME calculations provide for the lowest five years of earnings to be dropped, young workers in part-time or temporary work face a net marginal tax rate at or about the statutory 11.2 percent. This drops to 6.70 percent at age 25 , to 4.98 percent at age 45 and to 2.32 percent at age $60 .^{20}$ These unequal marginal tax rates, if recognized by the employees themselves, would distort labor supply toward more work in later years and less in earlier years than an equal present value tax with a constant marginal rate by age. Even if employees do not anticipate these declining marginal tax

\footnotetext{
${ }^{19}$ The one range in which the decline is not particularly sharp is males with dependent spouses who are younger than 35. This is attributable to the reduction in the number of years that are used in the AIME calculation for widow's benefits when the worker dies very early. For instance, a worker who dies at 27 will have only 2 years in the calculation of his AIME, which implies a $(1 / 2) /(1 / 35)=17.5$ times larger effect on a widow PIA than on a retirement PIA. This effect is naturally mitigated by the extremely low probability of such an early death. Nonetheless, its consequences for the marginal tax rate are perceptible for very young workers.

${ }^{20}$ The tax rates presented in the text, tables, and appendix are all done according to the rules that apply to each age cohort as of 1990. They are useful for addressing the distortions that exist in the program as it is today. Thus, part of the variation in tax rates by age is due to different rules regarding the normal retirement age and delayed retirement credit (in the case where the worker retires at 70). The calculations have also been done applying the same rules to each age. The pattern of declining tax rates with age still remains but is less severe at higher ages. None of the analysis or conclusions made in the paper are affected.
} 
rates, the unequal marginal tax rates at different times is likely to imply a greater excess burden than that of an equal present value tax with a constant marginal rate by age.

Female employees face lower marginal tax rates at each age and the differences become greater at older ages. The male-female difference increases from 2.17 percentage points at age 25 (when men face a 6.70 percent rate and women a 4.53 percent rate) to 2.83 percentage points at age 60 (when men face a 2.32 percent rate and women a net subsidy of 0.51 percent). This rate difference reflects the greater life expectancy of women since all other factors affecting benefits are exactly the same in these comparisons. To the extent that the elasticity of labor supply is greater for female employees than for males, the lower marginal tax rate for females is a desirable feature of the current social security rules.

The figures in column 3 of Table 1 show that male employees with dependent spouses (male employees who expect that their earnings will be the basis for benefits to dependent and surviving spouses) face very much lower marginal tax rates that are actually negative, i.e. they receive a net marginal subsidy. ${ }^{21}$ By age 60 the marginal tax rate is -5.97 percent and can offset a substantial portion of the marginal personal income tax. Once again there is a sharp difference in marginal social security tax rates between younger employees and older employees - the decline from -0.27 percent at age 25 to a -5.97 percent at age 60 is 5.70 percentage points, which is even larger than the corresponding declines for single men and women. Although the social security program is designed to provide more benefits to retired couples than to single individuals and to incorporate a life

\footnotetext{
${ }^{21}$ Note that male employees need not be married to face a lower tax rate but only need to expect to be married when they retire. Since our calculations assume a married employee with a wife two years younger than he (who therefore has a probability of dying before she can collect benefits) the tax rates in Table 1 for younger men who expect to marry in the future overstate the true net marginal social security tax.
} 
insurance annuity feature, the resulting difference in marginal tax rates does not as such serve any obvious social or economic purpose. Indeed, the unequal marginal tax rates distort the labor supply decisions of men with and without dependents.

The final column shows that women whose earnings are so low that they expect to collect benefits based on their husbands' earnings rather than their own face a very high social security marginal tax rate of 11.2 percent on top of their personal income tax marginal rate. Thus, a 55 year old married man with a 15 percent marginal personal income tax rate faces a combined income and social security tax rate of 10.34 percent ( 15 percent personal income tax minus the 4.66 percent negative social security marginal tax rate) while his wife faces a combined marginal tax rate of 26.2 percent (15 percent personal income tax plus the 11.2 marginal social security tax rate). This substantial discrepancy distorts the intrafamilial labor supply decision, encouraging more work by the husband and less by the wife.

Turning next to the bottom two panels of Table 1, in which we present the net marginal tax rates assuming discount rates of 4 percent and 6 percent, three patterns emerge. First, higher discount rates systematically reduce the value of the benefits paid in the future, thereby increasing the net tax rates for each type of worker. Changing the discount rate from 2 percent to 4 percent increases the net tax rates by roughly 2.5 percentage points for single males, 4 percentage points for single females, and 6 percentage points for males with dependent spouses. The corresponding increases when the discount rate is increased from 4 percent to 6 percent are 1.5, 2, and 3 percentage points. Second, increasing the discount rate reduces the demographic differences in net tax rates because those differences are the result of differential mortality rates being applied to future benefits; when the future is more heavily discounted, these differences are less important. Finally, higher 
discount rates increase the differences in tax rates by age in each demographic group for precisely the same reason; people closer to receiving benefits are discounting them over fewer years, so a higher discount rate is less critical for them. We focus our analysis in this paper on a discount rate of 2 percent, because this corresponds to the real after-tax rate of return on a security yielding an 8 percent return with 4 percent inflation and a 25 percent marginal tax rate.

The social security law has been modified in recent years to reduce the bias against continued work after the normal retirement age. Since our focus is on the impact of social security on the marginal dollar earned, we cannot ascertain completely whether this objective has been met. Our study requires us to consider only the later retirement date and the delayed retirement credit associated with working until 70 instead of the normal retirement age. To answer the question of whether the overall rate of return on social security contributions is higher when retirement is delayed would also require us to know the total payroll taxes paid during the extra years of work and whether any of these years change the level of the AIME at retirement (see, for example, Blinder, Gordon, and Wise (1980)).

The questions that we naturally can address are whether the net marginal social security tax rate differs between the two retirement strategies and whether the recent modifications to the laws have narrowed the gap. The figures presented in Table 2 suggest that the answer to both questions is yes. The tax rates in Table 2 are parallel to those in the top panel of Table 1 but are based on retirement at age 70; the differences between the tax rates associated with retirement at age 70 and retirement at the normal retirement age are shown in parentheses. 
Table 2

Effect of Delaying Retirement to Age 70 on

Social Security Marginal Tax Rates

of Middle Income Employees

Marginal Social Security Tax Rates with Retirement at Age 70

(Differences from "normal age" retirement shown in parentheses)

\begin{tabular}{cccc}
\hline $\begin{array}{c}\text { Age in } \\
1990\end{array}$ & $\begin{array}{c}\text { Male without } \\
\text { Social Security } \\
\text { Dependent Spouse }\end{array}$ & $\begin{array}{c}\text { Female without } \\
\text { Social Security } \\
\text { Dependent Spouse }\end{array}$ & $\begin{array}{c}\text { Male with } \\
\text { Dependent } \\
\text { Spouse }\end{array}$ \\
\hline \multirow{2}{*}{25} & 6.95 & 4.51 & -0.60 \\
& $(0.25)$ & $(0.02)$ & $(-0.33)$ \\
35 & 6.18 & 3.37 & -1.29 \\
& $(0.38)$ & $(-0.01)$ & $(-0.52)$ \\
45 & 5.46 & 2.36 & -2.56 \\
& $(0.48)$ & $(0.00)$ & $(-0.43)$ \\
55 & 4.53 & 1.25 & -4.16 \\
& $(1.28)$ & $(0.82)$ & $(0.50)$ \\
60 & 4.18 & 1.01 & -4.58 \\
& $(1.86)$ & $(1.52)$ & $(1.39)$ \\
\hline
\end{tabular}

"Middle Income Employees" expect a marginal PIA-to-AIME ratio of 0.32 and a personal income tax of 0.15 on half of benefits.

As we might expect, the change in the retirement age from the normal retirement to age 70 does not change the pattern observed in Table 1 that tax rates are higher at all ages for males than for females and lower still for males with dependent spouses. The numbers in parentheses show that the differences in tax rates between retirement strategies follows this ordering as well. At age 25 for example, a male without a dependent spouse faces a net tax rate of 6.95 percent, which is 0.25 percentage points higher than if he retired at his normal retirement age of 67 , whereas the tax rate for a female without a dependent spouse is 4.51 percent $(0.02$ higher than at the normal retirement 
age $)$ and the rate for a male with a dependent spouse is $-0.60(0.33$ lower than at the normal retirement age). The gains to postponing retirement to obtain the delayed retirement credit increase with the longevity of the household after retirement. The survival probabilities of women are higher than those of men, and the probability of at least one member of a retired couple surviving is higher than for either individual alone. These differences in survival probabilities, along with the presence of the dependent spouse benefit, explain the variation in both the level of the tax rate and its difference across retirement strategies in each row of Table $2 .{ }^{22}$

Consider next the effect of the employee's earnings level on the net marginal social security tax rate. Approximately six percent of all employees have earnings above the maximum taxable level (\$51,300 in 1990). Workers in this very high income group pay no social security tax on additional earnings and accrue no additional benefits if their earnings increase. Their marginal social security tax rate is thus zero. Below the maximum taxable level, however, the higher income employees face substantially higher net marginal social security tax rates than those with lower earnings.

\footnotetext{
${ }^{22}$ The comparison between the marginal rates for those who plan to retire at 62 versus the normal retirement age is similar. The benefits of these retirees are reduced by 6.67 percent per year for the first three years of benefit receipt before the normal retirement age and 5 percent per year for up to two additional years. The effects of the reduction and the extra years of benefit receipt essentially cancel each other out for single women, as in the case of delayed retirement. Single men generally face a marginal tax rate not more than one percent lower relative to retiring at the normal retirement age, and men with dependent spouses face a marginal tax rate not more than one percentage point higher than retirement at the normal retirement age. As in the case of delayed retirement, the years of benefit receipt matter more for men whereas the actuarial adjustment matters more for one-earner couples. This general conclusion is yet another consequence of the differential mortality risks of men, women, and couples.
} 
Since the gross statutory tax rate is constant at 11.2 percent, the higher net marginal rate reflects the lower increment to benefits accrued per dollar of earnings by upper income employees. More specifically, individuals with average indexed annual earnings over $\$ 25,740$ in 1990 receive only 15 cents of additional primary insurance amount for each additional dollar of average indexed earnings instead of the 32 cents received by those with incomes between $\$ 4,272$ and $\$ 25,740$. This implies a 53 percent reduction in the incremental benefits per dollar of current earnings.

The higher marginal social security tax rates of individuals who have an incremental PIA-toAIME ratio of only 0.15 are shown in Table 3 . The differences between the rates for these upper income individuals and the previously presented rates for middle income individuals with an incremental PIA-to-AIME ratio of 0.32 are shown in parentheses in each cell of the table. The assumption that these groups continue to face a marginal personal income tax rate of 0.15 means that, if anything, these calculations understate the net marginal social security tax rate of individuals with relatively high earnings (but below the maximum taxable amount). If mortality rates for higher income households are lower than average, the benefits calculated for this group would be underestimated and the net tax rates overstated; the empirical significance of this remains to be analyzed.

A 25 year old upper income male without social security dependents faces a marginal tax rate of 9.09 percent, a level equal to 81 percent of the statutory 11.2 percent rate. Table 3 shows that this is 2.39 percentage points higher than the corresponding 6.70 percent marginal social security tax rate for middle income men aged 25. The gap between the marginal tax rates of middle and upper income employees widens as they age and is greater for females than for males and greater for those with a dependent spouse than for individuals without dependents. This pattern reflects the fact that 
the present actuarial value of benefits rises with age and is highest among men with dependent spouses and higher among women than among men. 
Table 3

Comparisons of Social Security Marginal

Tax Rates of Middle and Upper Income Individuals

\begin{tabular}{cccc}
\hline & \multicolumn{2}{c}{$\begin{array}{c}\text { Marginal Social Security Tax Rates of Upper Income Individuals } \\
\text { (Differences from Middle Income Tax Rates shown in parentheses) }\end{array}$} \\
\hline \multirow{2}{*}{$\begin{array}{c}\text { Male without } \\
\text { Social Security }\end{array}$} & $\begin{array}{c}\text { Female without } \\
\text { Social Security }\end{array}$ & $\begin{array}{c}\text { Male with } \\
\text { Dependent } \\
\text { Spouse }\end{array}$ \\
\hline \multirow{2}{*}{25} & Dependent Spouse & Dependent Spouse & 5.82 \\
& 9.09 & 8.08 & $(6.09)$ \\
35 & $(2.39)$ & $(3.55)$ & 5.59 \\
& 8.64 & 7.53 & $(6.36)$ \\
45 & $(2.86)$ & $(4.15)$ & 4.95 \\
& 8.28 & 7.06 & $(7.08)$ \\
55 & $(3.30)$ & $(4.70)$ & 3.77 \\
& 7.47 & 6.15 & $(8.43)$ \\
& $(4.22)$ & $(5.72)$ & 3.15 \\
& 7.04 & 5.71 & $(9.12)$ \\
\hline
\end{tabular}

"Middle income employees" expect a marginal PIA-to-AIME ratio of 0.32 while "upper income employees expect a marginal PIA-to-AIME ratio of 0.15. Calculations assume that both groups expect a personal income tax ratio of 0.15 on half of benefits and will retire at the "normal age" of retirement.

Thus, among men without dependents the difference in the tax rate between upper and middle income employees rises from 2.39 percentage points at age 25 to 4.72 percentage points at age 60 . For females without dependents, the difference in marginal social security tax rates between upper and middle income employees rises from 3.55 percentage points at age 25 to 6.22 percentage points at age 60 . Since incremental benefits are greatest for male employees with dependent spouses, the shift to the lower PIA-to-AIME of 0.15 has the greatest impact for this group. Among 25 year olds 
males with dependent spouses, the net marginal social security tax rises from -0.27 percent for the middle income group to 5.82 percent for those in the upper income group. Among 60 year olds, the negative 5.97 percent net marginal social security tax rate among middle income taxpayers is raised by 9.12 percentage points to a 3.15 percent positive tax rate.

In short, upper income employees who pay a social security payroll tax on incremental earnings face substantially higher marginal tax rates than those with lower incomes and the gap rises with age. The differences in tax rates between younger and older employees are smaller for upper income individuals than for those with lower earnings. Similarly the difference between the marginal tax rates of men with dependent spouses and the 11.2 percent statutory rate faced by those spouses is also smaller among upper income employees. Nevertheless, the same patterns of distortions by age, sex and dependency status exist for employees with higher lifetime earnings and the overall level of the distorting marginal tax rates is substantially higher than among those with more modest incomes.

We turn finally to the very unusual and highly distortionary structure of net marginal social security tax rates among employees with very low average indexed earnings. Table 4 shows that individuals whose marginal PIA-to-AIME ratio is 0.90 generally face negative net marginal social security tax rates, i.e., an incremental dollar of earnings results in an increased present actuarial value of benefits that exceeds the increased payroll tax. These negative marginal tax rates can be very large. For example, men over 40 with dependent spouses face marginal social security taxes that range from negative 25 percent at age 40 to negative 37 percent at age 60 . For some of these employees, the combination of the social security marginal tax rate and the marginal rate of personal income tax will actually be negative! 
Table 4

Negative Social Security Marginal Tax Rates

of Employees with Low Covered Earnings

(percent)

\begin{tabular}{cccc}
\hline $\begin{array}{c}\text { Age in } \\
1990\end{array}$ & $\begin{array}{c}\text { Male without } \\
\text { Social Security } \\
\text { Dependent Spouse }\end{array}$ & $\begin{array}{c}\text { Female without } \\
\text { Social Security } \\
\text { Dependent Spouse }\end{array}$ & $\begin{array}{c}\text { Male with } \\
\text { Dependent } \\
\text { Spouse }\end{array}$ \\
\hline 25 & -1.45 & -7.55 & -21.06 \\
35 & -4.04 & -10.80 & -22.47 \\
45 & -6.29 & -13.66 & -26.30 \\
55 & -11.17 & -19.10 & -33.40 \\
60 & -13.78 & -21.73 & -37.10 \\
\hline
\end{tabular}

Employees with "Low Covered Earnings" expect a marginal PIA-to-AIME ratio of 0.90. In 1990 this corresponds to average indexed annual earnings of less than $\$ 4,272$. Calculations assume "normal age" retirement and a personal income tax rate of 0.15 on half of benefits.

This anomalous situation arises because social security achieves its progressivity through the structure of benefits rather than through graduated tax rates. Moreover, since the benefit structure does not provide any fixed lump sum benefit for all retirees but relates all benefits to prior earnings, achieving the current degree of progressivity requires that there will be a range of incomes in which the benefits per dollar of additional earnings are so large that they greatly outweigh the incremental taxes, creating the observed pattern of extremely high negative marginal tax rates.

The individuals to whom the 0.90 incremental PIA-to-AIME ratio applies must have average indexed earnings per year of less than $\$ 4,272$ in 1990 . This group undoubtedly contains some very poor individuals whose lifetime earnings were depressed by a combination of very low earnings and substantial unemployment. But many individuals in the group had low average covered earnings 
during their lifetime because most of their employment was not covered by social security. Until the 1983 legislation, coverage was not compulsory for employees of the federal government or nonprofit institutions. Until the 1990 legislation, state and local government employees were not covered unless they chose to be. Even today, state and local government employees who are covered by a government pension need not pay social security taxes. Thus, there are still some persons not covered, and there are many more who have been covered for a short period of time. An individual who did a little work in covered employment, e.g., after retiring from government or in part time jobs while in the government, could have a very low AIME even though he or she had had relatively high lifetime earnings outside covered employment. Such low-AIME employees face the high negative marginal tax rates shown in Table $4 .^{23}$

Moreover, the very poor who are eligible at age 65 for the federally administered Supplemental Security Income (SSI) program receive benefits on a means-tested basis. ${ }^{24}$ Only the first $\$ 20$ of monthly social security payments are exempt from the income test; after that, SSI payments are reduced dollar for dollar with social security payments. Although this program technically supplements the poor individual's social security benefit, the actual effect is to provide a combined level of social security and SSI benefit that is essentially independent of the individual's

\footnotetext{
${ }^{23}$ When the 1983 legislation was passed, a provision was made for gradual reduction of the 0.90 conversion rate for employees first covered due to that legislation. The rate is now 0.40. Many of the older workers who were newly covered by social security were exempted from this reduction.

${ }^{24}$ The federal benefit amount was $\$ 386$ for an individual and $\$ 579$ for a married couple in 1990. Eligibility requires that an individual not have more than $\$ 2,000$ of other resources ( $\$ 3,000$ for a couple), excluding the value of a home, an automobile used for essential transportation, and various other items. States are permitted to supplement this amount at their discretion, and some are required to do so by law.
} 
social security benefit. For such individuals, additional pre-retirement earnings have no effect on total benefits after age 65 . The marginal social security tax rate for these truly low income individuals who qualify for SSI is thus the full 11.2 percent statutory rate. Similarly, people whose private pensions contain social security offset provisions (i.e. the amount the employer pays in benefits is the difference between the pension entitlement and the social security benefit) and whose pension entitlements exceed their social security benefits also get no additional benefits due to social security by earning another dollar and, therefore, face the full 11.2 percent statutory rate.

\section{Social Security Reforms to Change Marginal Tax Rates}

The analysis in this paper shows how current social security rules have created a hodgepodge of marginal social security tax rates that differ by age, sex, dependency status, and income in ways that defy serious economic or social justification. The existing pattern of marginal rates distorts the incentive for each individual to work at different ages and the division of work within the household. Although the net marginal rate of social security taxes is very low for some employees and actually negative for substantial numbers of employees, the full statutory 11.2 percent rate without any offsetting benefits applies to young workers, to women who will collect as dependents, and to the very poor. Net marginal rates that are close to the statutory rate apply to individuals with relatively high average lifetime incomes but very high income individuals have a zero marginal social security tax rate.

Modifications of existing rules could reduce some of these distorting incentives without changing the basic structure of the social security program or its overall net cost. This paper cannot present a full evaluation of such possible reforms since that would require estimates of the total costs 
of alternative features and not just of their effects on marginal tax rates. It is nevertheless interesting to consider what changes in program rules could reduce or eliminate some of the distortions created by the current system.

Tax rates that differ by age. Perhaps the easiest distortion to eliminate is the different marginal tax rates that individuals face during their working life. There are two separate problems. First, very young workers face the full statutory tax rate of 11.2 percent because earnings in those years are not likely to be one of their best 35 years of earnings used to calculate the average indexed monthly earnings. Second, even when the earnings do count, the net marginal tax rate is higher for younger workers than for older workers. Table 1 showed that for men the net marginal tax rate falls from 6.7 percent at age 25 to 2.3 percent at age 60 ; the decline is even greater for single women and for men with dependent spouses.

The first distortion could be eliminated by including every year's earnings in the calculation of the AIME. The more general problem that net marginal tax rates decrease with the employee's age could be eliminated by replacing the current unweighted AIME calculation with a calculation that implicitly provides a real return on tax payments by taking the individual's age into account in weighting each year's earnings. An appropriate set of age-related weights would reflect both the number of years remaining until normal retirement age and the mortality probabilities. Such a revision of the AIME calculation would not redistribute benefits among individuals but would eliminate the distortions caused by the current inverse relation between age and social security marginal tax rates. ${ }^{25}$

\footnotetext{
${ }^{25}$ It is of course possible that the optimal set of age specific tax rates would not be uniform because of age-specific differences in labor supply elasticities. If the information needed for designing such an optimal tax schedule could be estimated it should of course be
} 
Differences in tax rates between men and women. The higher marginal tax rates for male employees without dependents than for female employees without dependents raises more difficult issues. There is first a basic question of horizontal equity: Does the equal treatment of men and women require that they face the same tax and benefit schedules or that the schedules be modified in such a way that otherwise equally situated men and women have the same net tax burden? The current law is sex-blind but results in a higher rate of return for women and more favorable net marginal tax rates. Looking beyond the question of horizontal equity, efficiency considerations suggest that a lower net marginal tax for women employees may be optimal. Since research on labor supply indicates that female employees (particularly married women) have greater supply elasticities than men (see Hausman (1981) and (1985) for estimates), the overall excess burden of the tax distortion will be lower if women face lower marginal tax rates than men. There is of course no reason to think that the existing differential is at the optimal level, because the differential is based on mortality and the optimal rates are determined by elasticities.

Moreover, the important difference in labor supply elasticities may not be between men and women as such but between married women and all other workers. If so, an efficient tax schedule would require a lower net marginal tax rate for married women than for other employees. This could be achieved by modifying the tax for married women (e.g., through a rebatable income tax credit for a portion of the social security taxes paid by a second earner).

incorporated in the modified AIME calculation.

Additionally, the optimal tax at each age would ideally account for the moral hazard problem involved with the provision of retirement insurance. That is, social security is designed to transfer resources to those who outlive their means, but as people age they have greater discretion as to how large their wealth will be once they retire by adjusting their labor supply. A tax rate that declines with age encourages workers not to retire "too early." 
The high marginal tax rate on married women. A much bigger marginal tax rate difference exists between married women who will claim benefits as a dependent or nondependent spouse and all other employees. Because an employee who will claim spouse and/or survivor benefits based on her husband's earnings history gets far less if any credit for the social security taxes that she pays, her net marginal social security tax rate is close to or at the full statutory 11.2 percent. When added to the regular federal and state personal income taxes this could easily produce an overall marginal tax rate close to 50 percent. ${ }^{26}$ As we noted above, married women have a higher than usual elasticity of labor supply, increasing the distorting effect and excess burden caused by the high marginal tax rate. In addition, the husbands of such women face substantially lower marginal tax rates because their marginal earnings produce benefits for their spouses as well as for themselves. As Table 1 showed, a 35 year old male employee with a dependent spouse has a net marginal social security tax of negative 0.77 percent while a 45 year old has a negative 2.13 percent net marginal social security tax. Thus, while a married woman may face a combined marginal tax rate of 45 percent, her husband would only face a combined marginal tax rate of only about 33 percent.

Reducing or eliminating the gap in tax rates within each married couple could be achieved by pooling the couple's social security earnings and taxes and dividing them equally between both members. Married women would then receive benefits in their own right when they reach retirement age rather than as dependents. Because of their greater longevity, the married women would generally face lower marginal tax rates than their husbands, an outcome that is probably a further

\footnotetext{
${ }^{26}$ In 1990 a couple with taxable income over $\$ 32,450$ faced a federal marginal personal income tax rate of 28 percent. Almost all states have income taxes. At this level of income, the marginal tax rates vary between 5 percent and 10 percent. The combined marginal tax rate is therefore generally greater than 45 percent and occasionally reaches 50 percent.
} 
step in the direction of optimal taxation because of their greater labor supply sensitivity. The aggregate impact of such a change on the finances of the social security program would depend on the bivariate distribution of husbands' and wives' earnings and on the behavioral response to the shifts in marginal tax rates. Additional research on this subject could make an important contribution to tax reform.

Higher tax rates of those who plan delayed retirement. The differences between the tax rates of those who plan to retire at the normal retirement age and those who plan to continue working until age 70 were shown above to be the result of different mortality risks of men, women, and couples. If the reforms suggested for equalizing the marginal tax rates between groups are not enough to also resolve this problem, it is also possible to make the delayed retirement credit depend on sex and dependency status. The aggregate budgetary effect of such a change in the delayed retirement credit would depend on the way that employees respond to the adjusted marginal tax rate. In this context, it is important to recognize that a change in the social security retirement rules would in principle affect the behavior of younger workers even though they would not receive the additional benefits until many years in the future. For example, an increase in the delayed retirement credit would reduce the implicit marginal tax rate on current 45 year olds by nearly a full percentage point (see Table 2), causing them to raise their labor supply even though they will not receive the increased social security benefits until 25 years from now. The government budget would benefit from the increased personal income tax revenue as well as from the increased payroll tax revenue caused by the increased labor supply and would do so for many years before additional benefits had to be paid to these employees. 
High marginal social security taxes. Although the expectation of future benefits reduces the implicit net marginal social security tax for many moderate income employees, those with AIME values over $\$ 27,540$ in 1990 are subject to the quite high marginal rates of social security tax that vary between 5.7 percent and 9.1 percent for those without dependents (see Table 3). These marginal social security tax rates are a cause for serious concern because they are incremental to the federal and state personal income tax rates and to local sales taxes. Since the excess burden of marginal tax rates is proportional to the square of the total marginal tax rate, adding a 9 percent marginal social security tax rate to a 40 percent combined marginal rate of other taxes increases the excess burden by 50 percent.

The high marginal rates of social security tax reflect the reduction of the marginal PIA-toAIME ratio to only 0.15 above the $\$ 25,740$ income level. These high marginal tax rates can only be lowered by reducing the overall progressivity of the social security program or by reducing the average level of taxes and benefits. In considering the optimal level of social security benefits the potentially large distortion in labor supply caused by these high marginal tax rates should be taken into account. ${ }^{27}$

Negative marginal tax rates of low AIME employees. The large negative marginal tax rates of low AIME employees (see Table 4) mean that overall marginal tax rates differ substantially

\footnotetext{
${ }^{27}$ Feldstein (1985) discusses the optimal level of social security benefits in an economy with a completely elastic supply of labor at every age. In that context, the optimal level of benefits balances protection to those who would not save enough for their old age against the reduced rate of return in a pay-as-you-go social security program that individuals who would otherwise have saved for themselves are forced to accept. In the simplified model considered there, the optimal level of benefits is very much lower than the actual level of benefits in the United States. The current analysis of the distorting effect of social security on work incentives provides a further reason to prefer a small social security program.
} 
among different employees. Because many employees with low AIME are not low income individuals but employees whose primary employment was outside the social security system, the unequal marginal tax rates cannot be justified on distributional grounds and are a prima facia source of inefficiency. In the extreme, older male employees with dependent spouses have such large negative marginal social security tax rates that their combined marginal social security and personal income tax rates are negative, implying a distorting subsidy to their labor supply as well as a budget cost that requires greater distortionary taxes on other employees. The low AIME employees experience not only anomalous negative marginal tax rates but also very much higher overall rates of return on the total taxes that they pay to the social security program during their working lives.

The appropriate policy response to this depends on the actual circumstances of the low AIME retirees. Separate policies could be designed for those who are poor and for individuals who have low AIMEs because their primary employment was not covered by social security. To some extent the means-tested Supplemental Security Program already achieves this.

One policy option would therefore be to reduce the 0.90 PIA-to-AIME ratio and to use the Supplemental Security Program to protect poor retirees on a means-tested basis. An alternative and more complex option would be to "integrate" social security benefits and the pensions paid by the federal and state governments by using a lower PIA-to-AIME ratio for retirees who are entitled to federal and state pensions. ${ }^{28}$

\footnotetext{
${ }^{28} \mathrm{~A}$ relatively simple and straightforward way to do this would be to regard such government pensions as a substitute for social security and to treat the value of such pensions as equivalent to a primary insurance amount in uncovered employment ("PIAUE"). The social security AIME would then be converted to an additional social security PIA using the marginal PIA-to-AIME ratio that corresponds to the initial level of the PIAUE. Thus, an individual who receives a $\$ 10,000$ a year pension from the federal and/or state governments would convert a low level AIME to additional social security benefits at
} 


\section{Concluding Comments}

This paper has documented the very substantial variation that currently exists among the net marginal social security tax rates of individuals who differ by age, sex, dependency status, retirement plans, and income. These differences are too important to ignore in assessing the effects of the tax system on labor supply, on unemployment, and other matters of economic behavior.

In addition, the marginal tax rate differences are potentially the source of inefficient distortions of labor supply that cannot be justified in terms of distributional or other goals. Although we have identified a number of options that could reduce the existing distortions, a complete analysis of the appropriate ways to correct the problems identified in this paper would require additional information on the overall budget costs of alternative benefit and tax rules.

Cambridge, MA

November 1991

an incremental ratio of 0.32 instead of 0.90 . A system much like this was implemented when several types of government employees were compelled to begin participating in the mid-1980's. For more details, see Social Security Administration (1990). 


\section{References}

Blinder, Alan S., Gordon, Roger H., and Wise, Donald E. (1980) "Reconsidering the Work Disincentive Effects of Social Security," National Tax Journal. Vol. 33, No. 4. 431442.

Browning, Edgar K. (1985) "The Marginal Social Security Tax on Labor," Public Finance Quarterly. Vol. 13, No. 3. 227-251.

Burkhauser, Richard V., and Turner, John A. (1985) "Is the Social Security Payroll Tax a Tax?" Public Finance Quarterly. Vol. 13, No. 3. 253-267.

Detlefs, Dale R., and Myers, Robert J. (1990) Guide to Social Security and Medicare 1991. (Louisville: William Mercer, Inc.).

Faber, Joseph F. (1982) Life Tables for the United States: 1900-2050. Social Security Administration, Office of the Actuary Actuarial Study 87. (Baltimore: Social Security Administration).

Feldstein, Martin S. (1974) "Unemployment Compensation: Adverse Incentives and Distributional Anomalies," National Tax Journal. Vol. 27, No. 2. 231-244.

Feldstein, Martin S. (1976) "Temporary Layoffs in the Theory of Unemployment," Journal of Political Economy. Vol. 84. 937-957.

Feldstein, Martin S. (1985) "The Optimal Level of Social Security Benefits," Quarterly Journal of Economics. Vol. 100, No. 2. 303-320.

Feldstein, Martin S. and Samwick, Andrew A. (1992) "Social Security Rules and Marginal Tax Rates," National Bureau of Economic Research Working Paper, No. 3962.

Gordon, Roger H. (1983) "Social Security and Labor Supply Incentives," Contemporary Policy Issues. Vol. 3. 16-22.

Hausman, Jerry A. (1981) "Labor Supply," in H. Aaron and J. Pechman (eds.) How Taxes Affect Economic Behavior. (Washington, DC: Brookings Institution), $27-72$.

Hausman, Jerry A. (1985) "Taxes and Labor Supply," in A. Auerbach and M. Feldstein (eds.) Handbook of Public Economics, Vol. I. (The Netherlands: North-Holland).

Musgrave, Richard A. (1959) The Theory of Public Finance. (New York: McGraw-Hill). 
Social Security Administration. (1990) Social Security Bulletin, Annual Statistical Supplement. (Washington, DC: U.S. Government Printing Office).

Solon, Gary (1985) "Work Incentive Effects of Taxing Unemployment Benefits," Econometrica. Vol. 53, No. 2. 295-306. 
Net Social Security Marginal Tax Rates

Marginal PIA/AIME: $\quad 0.90$

MTR on retirement income: 0.00

RETIRE AT NRA
RETIRE AT 70

AGE MALE FEMALE ONE-EARNER MALE FEMALE ONE-EARNER

\begin{tabular}{|c|c|c|c|c|c|c|}
\hline & -0.0186 & -0.0824 & -0.2453 & -0.0113 & -0.0831 & -0.2 \\
\hline & -0.0201 & 0845 & -0.2436 & .0127 & .0851 & 34 \\
\hline & -0.0216 & -0.0865 & -0.2416 & .0142 & -0.0872 & -0.2515 \\
\hline & -0.0232 & .0886 & 2393 & .0156 & .0893 & 2493 \\
\hline & -0.0248 & 0907 & 368 & 0171 & 0914 & \\
\hline & -0.0264 & 0.0928 & .2341 & 0186 & & \\
\hline & -0.0280 & -0.0950 & -0.2313 & 0202 & 0957 & \\
\hline & -0.0297 & -0.0971 & & 0217 & 0978 & \\
\hline & -0.0313 & 0.0993 & 284 & 0233 & 1001 & \\
\hline & -0.0330 & -0.1015 & 2293 & 0249 & 1023 & -0 \\
\hline & -0.0368 & -0.1062 & & 0279 & 1069 & \\
\hline & -0.0407 & -0.1110 & & & & \\
\hline & -0.0447 & -0.1159 & & & & \\
\hline & -0.0487 & & & & & \\
\hline & .0528 & & & & & \\
\hline & .0570 & & & & & \\
\hline & .0590 & & & & & \\
\hline & & & & & & \\
\hline & -0.06 & & & & & \\
\hline & -0.0653 & & & & & \\
\hline & -0.0675 & & & & & \\
\hline & -0.0698 & -0.1475 & & & & \\
\hline & -0.0721 & -0.1505 & & & -0.1504 & \\
\hline & -0.0746 & .1536 & -0 & 503 & & -0.3024 \\
\hline & -0.0771 & .1567 & -0.2934 & 627 & 567 & -0 \\
\hline & -0.0797 & -0.1600 & & & & -0 \\
\hline & -0.0825 & & & & & \\
\hline & -0.0882 & & & & & \\
\hline & -0.0941 & & & & & \\
\hline & -0.1003 & & & & & \\
\hline 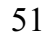 & -0.1068 & & & & & \\
\hline 52 & .1137 & & & & & \\
\hline 3 & & & & & & \\
\hline & & & & & & \\
\hline & -0.12 & & & & & \\
\hline 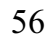 & & & & & & \\
\hline $5^{\prime}$ & -0.1400 & & & & & \\
\hline 5 & -0.1456 & & & & & \\
\hline & .1516 & & & & & \\
\hline & -0.1581 & -0.2440 & -0.4102 & & & -0.3678 \\
\hline & -0.1679 & -0.2544 & -0.4254 & -0.1092 & -0.2069 & -0.3816 \\
\hline & & & & & -0.2192 & \\
\hline & -0.2085 & -0.3007 & -0.4929 & -0.1361 & -0.2399 & -0.4326 \\
\hline
\end{tabular}


$\begin{array}{lllllll}64 & -0.2325 & -0.3272 & -0.5315 & -0.1491 & -0.2547 & -0.4554\end{array}$ 
Net Social Security Marginal Tax Rates

Marginal PIA/AIME: $\quad 0.90$

MTR on retirement income: 0.15

RETIRE AT NRA
RETIRE AT 70

MALE FEMALE ONE-EARNER

\begin{tabular}{|c|c|c|c|c|c|c|}
\hline 21 & -0.0088 & & & & & \\
\hline 22 & -0.0102 & -0.0697 & -0.2169 & -0.0034 & -0.0704 & -0.2260 \\
\hline & -0.0116 & -0.0716 & -0.21 & 0047 & & \\
\hline & -0.0131 & & & & & \\
\hline & 5 & & & & & \\
\hline & 0 & & & & & \\
\hline & -0.01 & & & & & \\
\hline & -0.0 & & & & & \\
\hline & -0.0 & & & & & \\
\hline & -0.0 & & & & & \\
\hline & -0.0 & & & & & \\
\hline & -0.0292 & & & & & \\
\hline & -0.0329 & & & & & \\
\hline & -0.0366 & & & & & \\
\hline & -0.0 & & & & & \\
\hline & -0.0 & & & & & \\
\hline & -0.0 & & & & & \\
\hline & & & & & & \\
\hline & -0.0 & & & & & \\
\hline & & & & & & \\
\hline & & & & & & \\
\hline & & & & & & \\
\hline & -( & & & & & \\
\hline & -0.0 & & & & & \\
\hline & -0.0 & & & & & \\
\hline & -0.0 & & & & & \\
\hline & -0.06 & & & & & \\
\hline 4 & $-0.0^{\prime}$ & & & & & \\
\hline & $-0.0^{\prime}$ & & & & & \\
\hline 50 & -0.0 & & & & & \\
\hline 51 & -0.0 & & & & & \\
\hline 5 & -0.0967 & & & & & \\
\hline & -0.10 & & & & & \\
\hline 5 & -0.1074 & & & & & \\
\hline & .1117 & & & & & \\
\hline & & & & & & \\
\hline 5 & -0.1211 & & & & & .3256 \\
\hline & -0.1262 & & & & & \\
\hline & -0.13 & & & & & \\
\hline & -0.1378 & -0.2173 & -0.3710 & -0.0854 & -0.1746 & -0.3318 \\
\hline
\end{tabular}




$\begin{array}{lllllll}61 & -0.1469 & -0.2269 & -0.3851 & -0.0926 & -0.1830 & -0.3445 \\ 62 & -0.1646 & -0.2473 & -0.4150 & -0.1021 & -0.1944 & -0.3628 \\ 63 & -0.1844 & -0.2697 & -0.4476 & -0.1174 & -0.2135 & -0.3917 \\ 64 & -0.2066 & -0.2943 & -0.4832 & -0.1295 & -0.2272 & -0.4128\end{array}$

Net Social Security Marginal Tax Rates

Marginal PIA/AIME: $\quad 0.90$

MTR on retirement income: 0.28

RETIRE AT NRA

AGE MALE FEMALE ONE-EARNER
RETIRE AT 70

MALE FEMALE ONE-EARNER

$\begin{array}{lllllll}21 & -0.0003 & -0.0552 & -0.1953 & 0.0060 & -0.0558 & -0.2036 \\ 22 & -0.0016 & -0.0570 & -0.1938 & 0.0047 & -0.0575 & -0.2022 \\ 23 & -0.0029 & -0.0587 & -0.1921 & 0.0035 & -0.0593 & -0.2006 \\ 24 & -0.0043 & -0.0605 & -0.1901 & 0.0022 & -0.0611 & -0.1987 \\ 25 & -0.0056 & -0.0623 & -0.1879 & 0.0010 & -0.0629 & -0.1967 \\ 26 & -0.0070 & -0.0641 & -0.1856 & -0.0004 & -0.0647 & -0.1945 \\ 27 & -0.0084 & -0.0660 & -0.1832 & -0.0017 & -0.0666 & -0.1922 \\ 28 & -0.0098 & -0.0679 & -0.1810 & -0.0030 & -0.0685 & -0.1900 \\ 29 & -0.0113 & -0.0697 & -0.1807 & -0.0044 & -0.0704 & -0.1899 \\ 30 & -0.0127 & -0.0717 & -0.1815 & -0.0057 & -0.0723 & -0.1908 \\ 31 & -0.0160 & -0.0757 & -0.1851 & -0.0083 & -0.0762 & -0.1952 \\ 32 & -0.0193 & -0.0798 & -0.1887 & -0.0110 & -0.0802 & -0.1996 \\ 33 & -0.0227 & -0.0840 & -0.1926 & -0.0138 & -0.0843 & -0.2044 \\ 34 & -0.0262 & -0.0882 & -0.1967 & -0.0165 & -0.0884 & -0.2094 \\ 35 & -0.0297 & -0.0925 & -0.2010 & -0.0194 & -0.0926 & -0.2145 \\ 36 & -0.0334 & -0.0969 & -0.2055 & -0.0223 & -0.0969 & -0.2199 \\ 37 & -0.0351 & -0.0992 & -0.2080 & -0.0238 & -0.0991 & -0.2226 \\ 38 & -0.0368 & -0.1014 & -0.2153 & -0.0255 & -0.1014 & -0.2255 \\ 39 & -0.0386 & -0.1038 & -0.2181 & -0.0271 & -0.1037 & -0.2284 \\ 40 & -0.0405 & -0.1062 & -0.2210 & -0.0288 & -0.1061 & -0.2314 \\ 41 & -0.0424 & -0.1086 & -0.2239 & -0.0306 & -0.1086 & -0.2345 \\ 42 & -0.0443 & -0.1111 & -0.2269 & -0.0324 & -0.1111 & -0.2377 \\ 43 & -0.0463 & -0.1137 & -0.2300 & -0.0343 & -0.1137 & -0.2410 \\ 44 & -0.0484 & -0.1164 & -0.2333 & -0.0362 & -0.1164 & -0.2444 \\ 45 & -0.0506 & -0.1191 & -0.2366 & -0.0382 & -0.1191 & -0.2479 \\ 46 & -0.0529 & -0.1219 & -0.2401 & -0.0403 & -0.1219 & -0.2515 \\ 47 & -0.0553 & -0.1248 & -0.2436 & -0.0425 & -0.1248 & -0.2553 \\ 48 & -0.0602 & -0.1304 & -0.2503 & -0.0439 & -0.1264 & -0.2583 \\ 49 & -0.0653 & -0.1362 & -0.2567 & -0.0478 & -0.1318 & -0.2655 \\ 50 & -0.0706 & -0.1422 & -0.2633 & -0.0492 & -0.1331 & -0.2676 \\ 51 & -0.0762 & -0.1484 & -0.2702 & -0.0534 & -0.1387 & -0.2752 \\ 52 & -0.0821 & -0.1548 & -0.2774 & -0.0547 & -0.1398 & -0.2771 \\ 53 & -0.0882 & -0.1615 & -0.2851 & -0.0591 & -0.1455 & -0.2851 \\ 54 & -0.0920 & -0.1655 & -0.2904 & -0.0591 & -0.1443 & -0.2841\end{array}$




$\begin{array}{lllllll}55 & -0.0960 & -0.1697 & -0.3027 & -0.0624 & -0.1482 & -0.2896 \\ 56 & -0.1002 & -0.1740 & -0.3087 & -0.0625 & -0.1471 & -0.2887 \\ 57 & -0.1047 & -0.1786 & -0.3151 & -0.0662 & -0.1513 & -0.2948 \\ 58 & -0.1095 & -0.1835 & -0.3220 & -0.0666 & -0.1505 & -0.2942 \\ 59 & -0.1147 & -0.1887 & -0.3293 & -0.0708 & -0.1550 & -0.3009 \\ 60 & -0.1203 & -0.1941 & -0.3371 & -0.0715 & -0.1545 & -0.3007 \\ 61 & -0.1287 & -0.2031 & -0.3501 & -0.0782 & -0.1622 & -0.3125 \\ 62 & -0.1452 & -0.2221 & -0.3779 & -0.0871 & -0.1729 & -0.3294 \\ 63 & -0.1636 & -0.2429 & -0.4082 & -0.1013 & -0.1906 & -0.3563 \\ 64 & -0.1842 & -0.2657 & -0.4414 & -0.1125 & -0.2033 & -0.3760\end{array}$

Net Social Security Marginal Tax Rates

Marginal PIA/AIME: $\quad 0.90$

MTR on retirement income: 0.32

RETIRE AT NRA

\begin{tabular}{|c|c|c|c|c|c|c|}
\hline $\mathrm{GB}$ & MALE & \multicolumn{2}{|c|}{ FEMALE } & ARNER & MALE & \\
\hline 21 & 0.0029 & -0.0504 & -0.1864 & 0.0090 & 0509 & \\
\hline 22 & 0.0017 & -0.0521 & -0.1849 & 0.0079 & .0526 & \\
\hline 23 & 0.0004 & -0.0538 & -0.1832 & 0067 & 0543 & \\
\hline 24 & -0.0009 & -0.0555 & -0.1813 & 0054 & 0561 & \\
\hline 25 & -0.0022 & -0.0572 & -0.1792 & 0.0042 & .0578 & \\
\hline 26 & -0.0036 & -0.0590 & -0.1770 & 0.0029 & -0.0596 & \\
\hline 27 & -0.0049 & -0.0608 & -0.1747 & 0.0016 & -0.0614 & \\
\hline 28 & -0.0063 & -0.0626 & -0.1725 & 0.0003 & -0.0632 & \\
\hline 29 & -0.0077 & .0645 & -0.1722 & & & \\
\hline 30 & -0.0091 & 63 & -0.1 & & & \\
\hline 31 & -0.0123 & .0702 & -0.1 & & & \\
\hline 32 & -0.0155 & .0742 & -0.1800 & 74 & & \\
\hline 33 & -0.0188 & .0783 & & & & \\
\hline 34 & -0.0222 & 24 & & & & \\
\hline 35 & -0.0256 & & & & & \\
\hline 36 & -0.02 & & & & & \\
\hline 37 & -0.0308 & .0930 & & & 30 & \\
\hline 38 & -0.0325 & .0952 & 2058 & & .0952 & \\
\hline 39 & -0.0342 & -0.0975 & 2085 & & .0975 & 5 \\
\hline 40 & -0.0360 & -0.0998 & -0.2113 & -0.0247 & -0.0998 & -0.2214 \\
\hline 41 & -0.0379 & -0.1022 & -0.2141 & -0.0264 & -0.1022 & -0.2244 \\
\hline 42 & -0.0398 & -0.1046 & -0.2171 & -0.0282 & -0.1046 & -0.2275 \\
\hline 43 & -0.0417 & -0.1072 & -0.2201 & -0.0300 & -0.1071 & -0.2307 \\
\hline 44 & -0.0438 & -0.1097 & -0.2232 & -0.0319 & -0.1097 & -0.2340 \\
\hline 45 & -0.0459 & -0.1124 & -0.2265 & -0.0338 & -0.1124 & -0.2374 \\
\hline 46 & -0.0481 & -0.1151 & -0.2298 & -0.0359 & -0.1151 & -0.2410 \\
\hline 47 & -0.0504 & -0.1179 & -0.2333 & -0.0380 & -0.1179 & -0.2446 \\
\hline 48 & -0.0552 & -0.1234 & -0.2398 & -0.0394 & -0.1195 & -0.2475 \\
\hline
\end{tabular}

RETIRE AT 70

EMALE ONE-EARNER

944 


$\begin{array}{lllllll}49 & -0.0601 & -0.1290 & -0.2459 & -0.0432 & -0.1247 & -0.2545 \\ 50 & -0.0653 & -0.1348 & -0.2523 & -0.0445 & -0.1260 & -0.2566 \\ 51 & -0.0707 & -0.1408 & -0.2591 & -0.0486 & -0.1314 & -0.2639 \\ 52 & -0.0764 & -0.1471 & -0.2661 & -0.0498 & -0.1324 & -0.2658 \\ 53 & -0.0824 & -0.1535 & -0.2735 & -0.0542 & -0.1380 & -0.2736 \\ 54 & -0.0861 & -0.1574 & -0.2787 & -0.0541 & -0.1369 & -0.2725 \\ 55 & -0.0899 & -0.1615 & -0.2906 & -0.0573 & -0.1406 & -0.2780 \\ 56 & -0.0940 & -0.1657 & -0.2965 & -0.0575 & -0.1396 & -0.2771 \\ 57 & -0.0984 & -0.1702 & -0.3027 & -0.0610 & -0.1437 & -0.2830 \\ 58 & -0.1031 & -0.1749 & -0.3093 & -0.0614 & -0.1428 & -0.2824 \\ 59 & -0.1081 & -0.1799 & -0.3164 & -0.0655 & -0.1473 & -0.2889 \\ 60 & -0.1135 & -0.1852 & -0.3240 & -0.0662 & -0.1467 & -0.2887 \\ 61 & -0.1217 & -0.1939 & -0.3367 & -0.0727 & -0.1543 & -0.3001 \\ 62 & -0.1377 & -0.2124 & -0.3637 & -0.0813 & -0.1646 & -0.3166 \\ 63 & -0.1556 & -0.2326 & -0.3931 & -0.0951 & -0.1818 & -0.3427 \\ 64 & -0.1756 & -0.2547 & -0.4253 & -0.1060 & -0.1942 & -0.3618\end{array}$

Net Social Security Marginal Tax Rates

Marginal PIA/AIME: $\quad 0.32$

MTR on retirement income: 0.00

RETIRE AT NRA
RETIRE AT 70

\section{AGE MALE FEMALE ONE-EARNER MALE FEMALE ONE-EARNER}

$\begin{array}{lllllll}21 & 0.0656 & 0.0429 & -0.0150 & 0.0682 & 0.0426 & -0.0185 \\ 22 & 0.0650 & 0.0421 & -0.0144 & 0.0677 & 0.0419 & -0.0179 \\ 23 & 0.0645 & 0.0414 & -0.0137 & 0.0671 & 0.0412 & -0.0172 \\ 24 & 0.0639 & 0.0407 & -0.0129 & 0.0666 & 0.0404 & -0.0165 \\ 25 & 0.0634 & 0.0399 & -0.0120 & 0.0661 & 0.0397 & -0.0156 \\ 26 & 0.0628 & 0.0392 & -0.0110 & 0.0655 & 0.0389 & -0.0147 \\ 27 & 0.0622 & 0.0384 & -0.0101 & 0.0650 & 0.0382 & -0.0138 \\ 28 & 0.0616 & 0.0376 & -0.0091 & 0.0645 & 0.0374 & -0.0129 \\ 29 & 0.0610 & 0.0369 & -0.0090 & 0.0639 & 0.0366 & -0.0128 \\ 30 & 0.0604 & 0.0361 & -0.0093 & 0.0633 & 0.0358 & -0.0132 \\ 31 & 0.0591 & 0.0344 & -0.0108 & 0.0622 & 0.0342 & -0.0150 \\ 32 & 0.0577 & 0.0327 & -0.0123 & 0.0611 & 0.0325 & -0.0168 \\ 33 & 0.0563 & 0.0310 & -0.0139 & 0.0600 & 0.0308 & -0.0188 \\ 34 & 0.0549 & 0.0292 & -0.0156 & 0.0589 & 0.0291 & -0.0209 \\ 35 & 0.0534 & 0.0274 & -0.0174 & 0.0577 & 0.0274 & -0.0230 \\ 36 & 0.0519 & 0.0256 & -0.0193 & 0.0565 & 0.0256 & -0.0252 \\ 37 & 0.0512 & 0.0247 & -0.0203 & 0.0558 & 0.0247 & -0.0264 \\ 38 & 0.0505 & 0.0238 & -0.0233 & 0.0552 & 0.0238 & -0.0275 \\ 39 & 0.0497 & 0.0228 & -0.0245 & 0.0545 & 0.0228 & -0.0287 \\ 40 & 0.0490 & 0.0218 & -0.0257 & 0.0538 & 0.0218 & -0.0300 \\ 41 & 0.0482 & 0.0208 & -0.0269 & 0.0531 & 0.0208 & -0.0312 \\ 42 & 0.0474 & 0.0197 & -0.0281 & 0.0523 & 0.0198 & -0.0326\end{array}$




$\begin{array}{lllllll}43 & 0.0465 & 0.0187 & -0.0294 & 0.0515 & 0.0187 & -0.0339 \\ 44 & 0.0457 & 0.0176 & -0.0308 & 0.0507 & 0.0176 & -0.0353 \\ 45 & 0.0448 & 0.0165 & -0.0321 & 0.0499 & 0.0165 & -0.0368 \\ 46 & 0.0438 & 0.0153 & -0.0336 & 0.0490 & 0.0153 & -0.0383 \\ 47 & 0.0428 & 0.0141 & -0.0350 & 0.0481 & 0.0141 & -0.0399 \\ 48 & 0.0408 & 0.0118 & -0.0378 & 0.0475 & 0.0134 & -0.0411 \\ 49 & 0.0387 & 0.0094 & -0.0404 & 0.0459 & 0.0112 & -0.0441 \\ 50 & 0.0365 & 0.0069 & -0.0431 & 0.0454 & 0.0107 & -0.0449 \\ 51 & 0.0342 & 0.0043 & -0.0460 & 0.0436 & 0.0084 & -0.0481 \\ 52 & 0.0318 & 0.0017 & -0.0490 & 0.0431 & 0.0079 & -0.0489 \\ 53 & 0.0292 & -0.0011 & -0.0522 & 0.0413 & 0.0056 & -0.0522 \\ 54 & 0.0277 & -0.0027 & -0.0544 & 0.0413 & 0.0060 & -0.0517 \\ 55 & 0.0260 & -0.0044 & -0.0594 & 0.0399 & 0.0044 & -0.0540 \\ 56 & 0.0243 & -0.0063 & -0.0619 & 0.0398 & 0.0049 & -0.0537 \\ 57 & 0.0224 & -0.0082 & -0.0646 & 0.0383 & 0.0031 & -0.0562 \\ 58 & 0.0204 & -0.0102 & -0.0674 & 0.0382 & 0.0035 & -0.0559 \\ 59 & 0.0183 & -0.0123 & -0.0704 & 0.0364 & 0.0016 & -0.0587 \\ 60 & 0.0160 & -0.0146 & -0.0737 & 0.0361 & 0.0018 & -0.0586 \\ 61 & 0.0125 & -0.0183 & -0.0791 & 0.0334 & -0.0014 & -0.0635 \\ 62 & 0.0057 & -0.0261 & -0.0906 & 0.0297 & -0.0058 & -0.0705 \\ 63 & -0.0019 & -0.0347 & -0.1031 & 0.0238 & -0.0131 & -0.0816 \\ 64 & -0.0105 & -0.0442 & -0.1168 & 0.0192 & -0.0184 & -0.0897\end{array}$

Net Social Security Marginal Tax Rates

Marginal PIA/AIME: $\quad 0.32$

MTR on retirement income: 0.15

RETIRE AT NRA RETIRE AT 70

AGE MALE FEMALE ONE-EARNER MALE FEMALE ONE-EARNER

$\begin{array}{lllllll}21 & 0.0690 & 0.0480 & -0.0055 & 0.0714 & 0.0478 & -0.0087 \\ 22 & 0.0685 & 0.0474 & -0.0050 & 0.0710 & 0.0472 & -0.0082 \\ 23 & 0.0680 & 0.0467 & -0.0043 & 0.0705 & 0.0465 & -0.0075 \\ 24 & 0.0675 & 0.0460 & -0.0035 & 0.0700 & 0.0458 & -0.0068 \\ 25 & 0.0670 & 0.0453 & -0.0027 & 0.0695 & 0.0451 & -0.0060 \\ 26 & 0.0665 & 0.0446 & -0.0018 & 0.0690 & 0.0444 & -0.0052 \\ 27 & 0.0659 & 0.0439 & -0.0009 & 0.0685 & 0.0437 & -0.0043 \\ 28 & 0.0654 & 0.0432 & -0.0000 & 0.0680 & 0.0430 & -0.0035 \\ 29 & 0.0649 & 0.0425 & 0.0001 & 0.0675 & 0.0423 & -0.0035 \\ 30 & 0.0643 & 0.0418 & -0.0002 & 0.0670 & 0.0415 & -0.0038 \\ 31 & 0.0631 & 0.0402 & -0.0016 & 0.0660 & 0.0400 & -0.0055 \\ 32 & 0.0618 & 0.0387 & -0.0030 & 0.0650 & 0.0385 & -0.0072 \\ 33 & 0.0605 & 0.0371 & -0.0045 & 0.0639 & 0.0369 & -0.0090 \\ 34 & 0.0592 & 0.0354 & -0.0061 & 0.0628 & 0.0354 & -0.0109 \\ 35 & 0.0578 & 0.0338 & -0.0077 & 0.0618 & 0.0337 & -0.0129 \\ 36 & 0.0564 & 0.0321 & -0.0094 & 0.0607 & 0.0321 & -0.0149\end{array}$




$\begin{array}{rrrrrrr}37 & 0.0558 & 0.0312 & -0.0104 & 0.0601 & 0.0313 & -0.0160 \\ 38 & 0.0551 & 0.0304 & -0.0132 & 0.0594 & 0.0304 & -0.0171 \\ 39 & 0.0544 & 0.0295 & -0.0142 & 0.0588 & 0.0295 & -0.0182 \\ 40 & 0.0537 & 0.0286 & -0.0153 & 0.0581 & 0.0286 & -0.0193 \\ 41 & 0.0530 & 0.0276 & -0.0165 & 0.0575 & 0.0276 & -0.0205 \\ 42 & 0.0522 & 0.0267 & -0.0176 & 0.0568 & 0.0267 & -0.0217 \\ 43 & 0.0514 & 0.0257 & -0.0188 & 0.0561 & 0.0257 & -0.0230 \\ 44 & 0.0506 & 0.0247 & -0.0200 & 0.0553 & 0.0247 & -0.0243 \\ 45 & 0.0498 & 0.0236 & -0.0213 & 0.0546 & 0.0236 & -0.0256 \\ 46 & 0.0489 & 0.0225 & -0.0226 & 0.0538 & 0.0226 & -0.0270 \\ 47 & 0.0480 & 0.0214 & -0.0240 & 0.0529 & 0.0214 & -0.0285 \\ 48 & 0.0462 & 0.0193 & -0.0266 & 0.0524 & 0.0208 & -0.0296 \\ 49 & 0.0442 & 0.0171 & -0.0290 & 0.0509 & 0.0188 & -0.0324 \\ 50 & 0.0422 & 0.0148 & -0.0315 & 0.0504 & 0.0183 & -0.0332 \\ 51 & 0.0400 & 0.0124 & -0.0342 & 0.0488 & 0.0161 & -0.0361 \\ 52 & 0.0378 & 0.0100 & -0.0369 & 0.0483 & 0.0157 & -0.0368 \\ 53 & 0.0354 & 0.0074 & -0.0399 & 0.0466 & 0.0135 & -0.0399 \\ 54 & 0.0340 & 0.0059 & -0.0419 & 0.0466 & 0.0140 & -0.0395 \\ 55 & 0.0325 & 0.0043 & -0.0466 & 0.0453 & 0.0125 & -0.0416 \\ 56 & 0.0308 & 0.0026 & -0.0489 & 0.0453 & 0.0129 & -0.0413 \\ 57 & 0.0291 & 0.0008 & -0.0514 & 0.0438 & 0.0113 & -0.0436 \\ 58 & 0.0273 & -0.0010 & -0.0540 & 0.0437 & 0.0116 & -0.0433 \\ 59 & 0.0253 & -0.0030 & -0.0567 & 0.0421 & 0.0099 & -0.0459 \\ 60 & 0.0232 & -0.0051 & -0.0597 & 0.0418 & 0.0101 & -0.0458 \\ 61 & 0.0199 & -0.0085 & -0.0647 & 0.0393 & 0.0071 & -0.0503 \\ 62 & 0.0136 & -0.0158 & -0.0754 & 0.0359 & 0.0031 & -0.0568 \\ 63 & 0.0066 & -0.0237 & -0.0870 & 0.0304 & -0.0037 & -0.0671 \\ 64 & -0.0013 & -0.0324 & -0.0996 & 0.0261 & -0.0086 & -0.0746\end{array}$

Net Social Security Marginal Tax Rates

Marginal PIA/AIME: $\quad 0.32$

MTR on retirement income: 0.28

RETIRE AT NRA RETIRE AT 70

AGE MALE FEMALE ONE-EARNER MALE FEMALE ONE-EARNER

$\begin{array}{lllllll}21 & 0.0721 & 0.0525 & 0.0027 & 0.0743 & 0.0523 & -0.0002 \\ 22 & 0.0716 & 0.0519 & 0.0033 & 0.0739 & 0.0517 & 0.0003 \\ 23 & 0.0711 & 0.0513 & 0.0039 & 0.0734 & 0.0511 & 0.0009 \\ 24 & 0.0707 & 0.0507 & 0.0046 & 0.0730 & 0.0505 & 0.0015 \\ 25 & 0.0702 & 0.0500 & 0.0054 & 0.0725 & 0.0498 & 0.0023 \\ 26 & 0.0697 & 0.0494 & 0.0062 & 0.0721 & 0.0492 & 0.0030 \\ 27 & 0.0692 & 0.0487 & 0.0070 & 0.0716 & 0.0485 & 0.0038 \\ 28 & 0.0687 & 0.0481 & 0.0078 & 0.0711 & 0.0478 & 0.0046 \\ 29 & 0.0682 & 0.0474 & 0.0079 & 0.0706 & 0.0472 & 0.0047 \\ 30 & 0.0677 & 0.0467 & 0.0077 & 0.0701 & 0.0465 & 0.0043\end{array}$




$\begin{array}{lllllll}31 & 0.0665 & 0.0453 & 0.0064 & 0.0692 & 0.0451 & 0.0028 \\ 32 & 0.0653 & 0.0438 & 0.0051 & 0.0683 & 0.0437 & 0.0012 \\ 33 & 0.0641 & 0.0423 & 0.0037 & 0.0673 & 0.0422 & -0.0005 \\ 34 & 0.0629 & 0.0408 & 0.0022 & 0.0663 & 0.0407 & -0.0023 \\ 35 & 0.0616 & 0.0393 & 0.0007 & 0.0653 & 0.0392 & -0.0041 \\ 36 & 0.0603 & 0.0377 & -0.0009 & 0.0643 & 0.0377 & -0.0060 \\ 37 & 0.0597 & 0.0369 & -0.0018 & 0.0637 & 0.0369 & -0.0070 \\ 38 & 0.0591 & 0.0361 & -0.0044 & 0.0631 & 0.0361 & -0.0080 \\ 39 & 0.0584 & 0.0353 & -0.0054 & 0.0625 & 0.0353 & -0.0090 \\ 40 & 0.0578 & 0.0344 & -0.0064 & 0.0619 & 0.0344 & -0.0101 \\ 41 & 0.0571 & 0.0336 & -0.0074 & 0.0613 & 0.0336 & -0.0112 \\ 42 & 0.0564 & 0.0327 & -0.0085 & 0.0607 & 0.0327 & -0.0123 \\ 43 & 0.0557 & 0.0317 & -0.0096 & 0.0600 & 0.0318 & -0.0135 \\ 44 & 0.0550 & 0.0308 & -0.0108 & 0.0593 & 0.0308 & -0.0147 \\ 45 & 0.0542 & 0.0298 & -0.0120 & 0.0586 & 0.0298 & -0.0160 \\ 46 & 0.0534 & 0.0288 & -0.0132 & 0.0578 & 0.0288 & -0.0173 \\ 47 & 0.0525 & 0.0278 & -0.0144 & 0.0571 & 0.0278 & -0.0186 \\ 48 & 0.0508 & 0.0258 & -0.0168 & 0.0566 & 0.0272 & -0.0197 \\ 49 & 0.0490 & 0.0237 & -0.0191 & 0.0552 & 0.0253 & -0.0222 \\ 50 & 0.0471 & 0.0216 & -0.0214 & 0.0547 & 0.0248 & -0.0230 \\ 51 & 0.0451 & 0.0194 & -0.0239 & 0.0532 & 0.0229 & -0.0257 \\ 52 & 0.0430 & 0.0171 & -0.0265 & 0.0527 & 0.0225 & -0.0263 \\ 53 & 0.0408 & 0.0148 & -0.0292 & 0.0512 & 0.0205 & -0.0292 \\ 54 & 0.0395 & 0.0133 & -0.0311 & 0.0512 & 0.0209 & -0.0288 \\ 55 & 0.0380 & 0.0119 & -0.0354 & 0.0500 & 0.0195 & -0.0308 \\ 56 & 0.0365 & 0.0103 & -0.0376 & 0.0499 & 0.0199 & -0.0305 \\ 57 & 0.0350 & 0.0087 & -0.0399 & 0.0486 & 0.0184 & -0.0326 \\ 58 & 0.0332 & 0.0069 & -0.0423 & 0.0485 & 0.0187 & -0.0324 \\ 59 & 0.0314 & 0.0051 & -0.0449 & 0.0470 & 0.0171 & -0.0348 \\ 60 & 0.0294 & 0.0032 & -0.0477 & 0.0467 & 0.0173 & -0.0347 \\ 61 & 0.0264 & -0.0000 & -0.0523 & 0.0444 & 0.0145 & -0.0389 \\ 62 & 0.0205 & -0.0068 & -0.0622 & 0.0412 & 0.0107 & -0.0449 \\ 63 & 0.0140 & -0.0142 & -0.0730 & 0.0362 & 0.0044 & -0.0545 \\ 64 & 0.0067 & -0.0223 & -0.0848 & 0.0322 & -0.0001 & -0.0615\end{array}$

Net Social Security Marginal Tax Rates

Marginal PIA/AIME: $\quad 0.32$

MTR on retirement income: 0.33

RETIRE AT NRA

RETIRE AT 70

\begin{tabular}{lcccccc} 
AGE & MALE & \multicolumn{2}{c}{ FEMALE } & ONE-EARNER & MALE & FEMA \\
& & & & & & \\
21 & 0.0732 & 0.0543 & 0.0059 & 0.0754 & 0.0541 & 0.0030 \\
22 & 0.0728 & 0.0537 & 0.0064 & 0.0750 & 0.0535 & 0.0035 \\
23 & 0.0723 & 0.0531 & 0.0070 & 0.0745 & 0.0529 & 0.0041 \\
24 & 0.0719 & 0.0524 & 0.0077 & 0.0741 & 0.0522 & 0.0047
\end{tabular}




$\begin{array}{lllllll}25 & 0.0714 & 0.0518 & 0.0085 & 0.0737 & 0.0516 & 0.0054 \\ 26 & 0.0709 & 0.0512 & 0.0093 & 0.0732 & 0.0510 & 0.0062 \\ 27 & 0.0704 & 0.0506 & 0.0101 & 0.0728 & 0.0503 & 0.0070 \\ 28 & 0.0699 & 0.0499 & 0.0109 & 0.0723 & 0.0497 & 0.0077 \\ 29 & 0.0694 & 0.0493 & 0.0109 & 0.0718 & 0.0490 & 0.0078 \\ 30 & 0.0690 & 0.0486 & 0.0107 & 0.0714 & 0.0484 & 0.0075 \\ 31 & 0.0678 & 0.0472 & 0.0094 & 0.0705 & 0.0470 & 0.0059 \\ 32 & 0.0667 & 0.0458 & 0.0082 & 0.0695 & 0.0456 & 0.0044 \\ 33 & 0.0655 & 0.0443 & 0.0068 & 0.0686 & 0.0442 & 0.0028 \\ 34 & 0.0643 & 0.0429 & 0.0054 & 0.0676 & 0.0428 & 0.0011 \\ 35 & 0.0631 & 0.0414 & 0.0039 & 0.0667 & 0.0414 & -0.0007 \\ 36 & 0.0618 & 0.0399 & 0.0024 & 0.0657 & 0.0399 & -0.0026 \\ 37 & 0.0612 & 0.0391 & 0.0015 & 0.0651 & 0.0391 & -0.0035 \\ 38 & 0.0606 & 0.0383 & -0.0010 & 0.0645 & 0.0383 & -0.0045 \\ 39 & 0.0600 & 0.0375 & -0.0020 & 0.0640 & 0.0375 & -0.0055 \\ 40 & 0.0594 & 0.0367 & -0.0029 & 0.0634 & 0.0367 & -0.0065 \\ 41 & 0.0587 & 0.0358 & -0.0040 & 0.0628 & 0.0358 & -0.0076 \\ 42 & 0.0580 & 0.0350 & -0.0050 & 0.0622 & 0.0350 & -0.0087 \\ 43 & 0.0573 & 0.0341 & -0.0061 & 0.0615 & 0.0341 & -0.0098 \\ 44 & 0.0566 & 0.0332 & -0.0072 & 0.0608 & 0.0332 & -0.0110 \\ 45 & 0.0559 & 0.0322 & -0.0084 & 0.0601 & 0.0322 & -0.0122 \\ 46 & 0.0551 & 0.0312 & -0.0095 & 0.0594 & 0.0313 & -0.0135 \\ 47 & 0.0543 & 0.0303 & -0.0108 & 0.0587 & 0.0303 & -0.0148 \\ 48 & 0.0526 & 0.0283 & -0.0131 & 0.0582 & 0.0297 & -0.0158 \\ 49 & 0.0508 & 0.0263 & -0.0153 & 0.0568 & 0.0278 & -0.0183 \\ 50 & 0.0490 & 0.0242 & -0.0175 & 0.0564 & 0.0274 & -0.0190 \\ 51 & 0.0470 & 0.0221 & -0.0199 & 0.0549 & 0.0255 & -0.0217 \\ 52 & 0.0450 & 0.0199 & -0.0224 & 0.0545 & 0.0251 & -0.0223 \\ 53 & 0.0429 & 0.0176 & -0.0251 & 0.0529 & 0.0231 & -0.0251 \\ 54 & 0.0416 & 0.0162 & -0.0269 & 0.0529 & 0.0235 & -0.0247 \\ 55 & 0.0402 & 0.0148 & -0.0312 & 0.0518 & 0.0222 & -0.0266 \\ 56 & 0.0387 & 0.0133 & -0.0332 & 0.0518 & 0.0225 & -0.0263 \\ 57 & 0.0372 & 0.0117 & -0.0355 & 0.0505 & 0.0211 & -0.0284 \\ 58 & 0.0355 & 0.0100 & -0.0378 & 0.0503 & 0.0214 & -0.0282 \\ 59 & 0.0337 & 0.0082 & -0.0403 & 0.0489 & 0.0198 & -0.0305 \\ 60 & 0.0318 & 0.0063 & -0.0430 & 0.0486 & 0.0200 & -0.0305 \\ 61 & 0.0289 & 0.0032 & -0.0475 & 0.0463 & 0.0173 & -0.0345 \\ 62 & 0.0232 & -0.0033 & -0.0571 & 0.0433 & 0.0137 & -0.0404 \\ 63 & 0.0169 & -0.0105 & -0.0676 & 0.0384 & 0.0075 & -0.0497 \\ 64 & 0.0097 & -0.0184 & -0.0790 & 0.0345 & 0.0031 & -0.0565 \\ & & & & & & \end{array}$

Net Social Security Marginal Tax Rates

Marginal PIA/AIME: $\quad 0.15$

MTR on retirement income: 0.00

RETIRE AT NRA

RETIRE AT 70 
AGE MALE FEMALE ONE-EARNER MALE FEMALE ONE-EARNER

\begin{tabular}{|c|c|c|c|c|c|c|}
\hline 21 & 0.0902 & 0.0796 & 0.0524 & 0.0914 & 0.0795 & 0.0508 \\
\hline 22 & 0.0900 & 0.0793 & 0.0527 & 0.0912 & 0.0791 & 0.0511 \\
\hline 23 & 0.0897 & 0.0789 & 0.0531 & 0.0910 & 0.0788 & 0.0514 \\
\hline 24 & 0.0895 & 0.0786 & 0.0535 & 0.0907 & 0.0785 & 0.0518 \\
\hline 25 & 0.0892 & 0.0782 & 0.0539 & 0.0905 & 0.0781 & 0.0522 \\
\hline 26 & 0.0889 & 0.0779 & 0.0543 & 0.0902 & 0.0777 & 0.0526 \\
\hline 27 & 0.0887 & 0.0775 & 0.0548 & 0.0900 & 0.0774 & 0.0530 \\
\hline 28 & 0.0884 & 0.0771 & 0.0552 & 0.0897 & 0.0770 & 0.0535 \\
\hline 29 & 0.0881 & 0.0768 & 0.0553 & 0.08 & 0.0767 & 0.0535 \\
\hline 30 & 0.0878 & 0.0764 & 0.05 & 0.08 & 0.0763 & 0.0533 \\
\hline 31 & 0.0872 & 0.0756 & & 0.08 & 0.0755 & 0.0525 \\
\hline 32 & 0.0866 & 0.0748 & 0.0537 & 0.0882 & 0.0747 & 0.0516 \\
\hline 33 & 0.0859 & 0.0740 & 0.0530 & 0.0876 & 0.0740 & 0.0507 \\
\hline 34 & 0.0852 & 0.0732 & 0.0522 & 0.0871 & 0.0732 & 0.0497 \\
\hline 35 & 0.0845 & 0.0724 & 0.0513 & 0.0865 & 0.0723 & 0.0487 \\
\hline 36 & 0.0838 & 0.0715 & 0.0505 & 0.0860 & 0.0715 & 0.0477 \\
\hline 37 & 0.0835 & 0.0711 & 0.0500 & 0.0857 & 0.0711 & 0.0471 \\
\hline 38 & 0.0832 & 0.0706 & 0.0486 & 0.0854 & 0.0706 & 0.0466 \\
\hline 39 & 0.0828 & 0.0702 & 0.0480 & 0.0850 & 0.0702 & 0.0460 \\
\hline 40 & 0.0825 & 0.0697 & 0.0475 & 0.0847 & 0.0697 & 0.0455 \\
\hline 41 & 0.0821 & 0.0692 & 0.0469 & 0.0844 & 0.0693 & 0.0449 \\
\hline 42 & 0.0817 & 0.0688 & 0.0463 & 0.0840 & 0.0688 & 0.0442 \\
\hline 43 & 0.0813 & 0.0683 & 0.0457 & 0.0837 & 0.0683 & 0.0436 \\
\hline 44 & 0.0809 & 0.0677 & 0.0451 & 33 & 0.0677 & 0.0429 \\
\hline 45 & 0.0805 & 0.0672 & 0.0444 & & 0.0672 & 0.0423 \\
\hline 46 & 0.0800 & 0.0667 & 0.0438 & & 0.0667 & 0.0415 \\
\hline 47 & 0.0796 & 0.0661 & 0.0431 & 0.0821 & 0.0661 & 0.0408 \\
\hline 48 & 0.0786 & 0.0650 & 0.0418 & 0.0818 & 0.0658 & 0.0402 \\
\hline 49 & 0.0776 & 0.0639 & 0.0406 & 0.0810 & 0.0648 & 0.0388 \\
\hline 50 & 0.0766 & 0.0627 & 0.0393 & 0.0808 & 0.0645 & 0.0384 \\
\hline 51 & 0.0755 & 0.0615 & 0.0379 & 0.0800 & 0.0634 & 0.0370 \\
\hline 52 & 0.0744 & 0.0603 & 0.0365 & 0.0797 & 0.0632 & 0.0366 \\
\hline 53 & 0.0732 & 0.0590 & 0.0350 & 0.0788 & 0.0621 & 0.0350 \\
\hline 54 & 0.0725 & 0.0582 & 0.0340 & 0.0788 & 0.0623 & 0.0352 \\
\hline 55 & 0.0717 & 0.0574 & 0.0316 & 0.0782 & 0.0616 & 0.0342 \\
\hline 56 & 0.0709 & 0.0566 & 0.0305 & 0.0782 & 0.0618 & 0.0343 \\
\hline 57 & 0.0700 & 0.0557 & 0.0292 & 0.0775 & 0.0610 & 0.0332 \\
\hline 58 & 0.0691 & 0.0547 & 0.0279 & 0.0774 & 0.0611 & 0.0333 \\
\hline 59 & 0.0681 & 0.0537 & 0.0265 & 0.0766 & 0.0602 & 0.0320 \\
\hline 60 & 0.0670 & 0.0527 & 0.0250 & 0.0764 & 0.0604 & 0.0320 \\
\hline 61 & 0.0654 & 0.0509 & 0.0224 & 0.0751 & 0.0589 & 0.0297 \\
\hline 62 & 0.0622 & 0.0473 & 0.0170 & 0.0734 & 0.0568 & 0.0265 \\
\hline 63 & 0.0586 & 0.0432 & 0.0112 & 0.0707 & 0.0534 & 0.0212 \\
\hline 64 & 0.0546 & 0.0388 & 0.0048 & 0.0685 & 0.0509 & 0.0174 \\
\hline
\end{tabular}

Net Social Security Marginal Tax Rates

Marginal PIA/AIME: $\quad 0.15$ 
MTR on retirement income: 0.15

RETIRE AT NRA

RETIRE AT 70

AGE MALE FEMALE ONE-EARNER MALE FEMALE ONE-EARNER

\begin{tabular}{|c|c|c|c|c|c|c|}
\hline 21 & 0.0919 & 0.0820 & 0.0569 & 0.0930 & 0.0819 & 0.0554 \\
\hline 22 & 0.0916 & 0.0817 & 0.0572 & 0.0928 & 0.0816 & 0.0557 \\
\hline 23 & 0.0914 & 0.0814 & 0.0575 & 0.0925 & 0.0813 & 0.0560 \\
\hline 24 & 0.0912 & 0.0811 & 0.0578 & 0.0923 & 0.0810 & 0.0563 \\
\hline 25 & 0.0909 & 0.0808 & 0.0582 & 0.0921 & 0.0806 & 0.0567 \\
\hline 26 & 0.0907 & 0.0804 & 0.0586 & 0.0919 & 0.0803 & 0.0571 \\
\hline 27 & 0.0904 & 0.0801 & 0.0591 & 0.0916 & 0.0800 & 0.0575 \\
\hline 28 & 0.0902 & 0.0798 & 0.0595 & 0.0914 & 0.0796 & 0.0579 \\
\hline 29 & 0.0899 & 0.0794 & 0.0595 & 0.0911 & 0.0793 & 0.0579 \\
\hline 30 & 0.0896 & 0.0791 & 0.0594 & 0.0909 & 0.0790 & 0.0577 \\
\hline 31 & 0.0891 & 0.0784 & 0.0587 & 0.0904 & 0.0783 & 0.0569 \\
\hline 32 & 0.0885 & 0.0776 & 0.0581 & 0.0899 & 0.0775 & 0.0561 \\
\hline 33 & 0.0878 & 0.0769 & 0.0574 & 0.0895 & 0.0768 & 0.0553 \\
\hline 34 & 0.0872 & 0.0761 & 0.0567 & 0.0890 & 0.0761 & 0.0544 \\
\hline 35 & 0.0866 & 0.0753 & 0.0559 & 0.0885 & 0.0753 & 0.0535 \\
\hline 36 & 0.0859 & 0.0745 & 0.0551 & 0.0879 & 0.0745 & 0.0525 \\
\hline 37 & 0.0856 & 0.0741 & 0.0546 & 0.0876 & 0.0741 & 0.0520 \\
\hline 38 & 0.0853 & 0.0737 & 0.0533 & 0.0874 & 0.0737 & 0.0515 \\
\hline 39 & 0.0850 & 0.0733 & 0.0528 & 0.0871 & 0.0733 & 0.0510 \\
\hline 40 & 0.0847 & 0.0729 & 0.0523 & 0.0868 & 0.0729 & 0.0504 \\
\hline 41 & 0.0843 & 0.0725 & 0.0518 & 0.0864 & 0.0725 & 0.0499 \\
\hline 42 & 0.0840 & 0.0720 & 0.0512 & 0.0861 & 0.0720 & 0.0493 \\
\hline 43 & 0.0836 & 0.0715 & 0.0507 & 0.0858 & 0.0715 & 0.0487 \\
\hline 44 & 0.0832 & 0.0711 & 0.0501 & 0.0854 & 0.0711 & 0.0481 \\
\hline 45 & 0.0828 & 0.0706 & 0.0495 & 0.0851 & 0.0706 & 0.0475 \\
\hline 46 & 0.0824 & 0.0701 & 0.0489 & 0.0847 & 0.0701 & 0.0468 \\
\hline 47 & 0.0820 & 0.0695 & 0.0482 & 0.0843 & 0.0696 & 0.0462 \\
\hline 48 & 0.0811 & 0.0685 & 0.0471 & 0.0841 & 0.0693 & 0.0456 \\
\hline 49 & 0.0802 & 0.0675 & 0.0459 & 0.0833 & 0.0683 & 0.0443 \\
\hline 50 & 0.0793 & 0.0664 & 0.0447 & 0.0831 & 0.0681 & 0.0440 \\
\hline 51 & 0.0783 & 0.0653 & 0.0435 & .0824 & 0.0671 & 0.0426 \\
\hline 52 & 0.0772 & 0.0642 & 0.0422 & 0.0821 & 0.0669 & 0.0423 \\
\hline 53 & 0.0761 & 0.0630 & 0.0408 & 0.0813 & 0.0658 & 0.0408 \\
\hline 54 & 0.0754 & 0.0623 & 0.0399 & 0.0813 & 0.0661 & 0.0410 \\
\hline 55 & 0.0747 & 0.0615 & 0.0377 & 0.0807 & 0.0654 & 0.0400 \\
\hline 56 & 0.0740 & 0.0607 & 0.0366 & 0.0807 & 0.0655 & 0.0402 \\
\hline 57 & 0.0732 & 0.0599 & 0.0354 & 0.0801 & 0.0648 & 0.0391 \\
\hline 58 & 0.0723 & 0.0590 & 0.0342 & 0.0800 & 0.0650 & 0.0392 \\
\hline 59 & 0.0714 & 0.0581 & 0.0329 & 0.0792 & 0.0641 & 0.0380 \\
\hline 60 & 0.0704 & 0.0571 & 0.0315 & 0.0791 & 0.0642 & 0.0380 \\
\hline 61 & 0.0688 & 0.0555 & 0.0292 & 0.0779 & 0.0628 & 0.0359 \\
\hline 62 & 0.0659 & 0.0521 & 0.0242 & 0.0763 & 0.0609 & 0.0329 \\
\hline 63 & 0.0626 & 0.0484 & 0.0187 & 0.0738 & 0.0578 & 0.0280 \\
\hline & 0.0589 & 0.0443 & 0.0128 & 0.0718 & 0.0555 & 0.0245 \\
\hline
\end{tabular}


Net Social Security Marginal Tax Rates

Marginal PIA/AIME: $\quad 0.15$

MTR on retirement income: 0.28

RETIRE AT NRA
RETIRE AT 70

$\begin{array}{lllllll}21 & 0.0933 & 0.0841 & 0.0608 & 0.0943 & 0.0840 & 0.0594 \\ 22 & 0.0931 & 0.0838 & 0.0610 & 0.0941 & 0.0837 & 0.0596 \\ 23 & 0.0928 & 0.0835 & 0.0613 & 0.0939 & 0.0834 & 0.0599 \\ 24 & 0.0926 & 0.0832 & 0.0616 & 0.0937 & 0.0832 & 0.0602 \\ 25 & 0.0924 & 0.0829 & 0.0620 & 0.0935 & 0.0828 & 0.0606 \\ 26 & 0.0922 & 0.0826 & 0.0624 & 0.0933 & 0.0825 & 0.0609 \\ 27 & 0.0919 & 0.0823 & 0.0628 & 0.0931 & 0.0822 & 0.0613 \\ 28 & 0.0917 & 0.0820 & 0.0632 & 0.0928 & 0.0819 & 0.0617 \\ 29 & 0.0915 & 0.0817 & 0.0632 & 0.0926 & 0.0816 & 0.0617 \\ 30 & 0.0912 & 0.0814 & 0.0631 & 0.0924 & 0.0813 & 0.0615 \\ 31 & 0.0907 & 0.0807 & 0.0625 & 0.0919 & 0.0806 & 0.0608 \\ 32 & 0.0901 & 0.0800 & 0.0619 & 0.0915 & 0.0800 & 0.0601 \\ 33 & 0.0895 & 0.0793 & 0.0612 & 0.0910 & 0.0793 & 0.0593 \\ 34 & 0.0890 & 0.0786 & 0.0605 & 0.0906 & 0.0786 & 0.0584 \\ 35 & 0.0884 & 0.0779 & 0.0598 & 0.0901 & 0.0779 & 0.0576 \\ 36 & 0.0878 & 0.0772 & 0.0591 & 0.0896 & 0.0772 & 0.0567 \\ 37 & 0.0875 & 0.0768 & 0.0587 & 0.0894 & 0.0768 & 0.0562 \\ 38 & 0.0872 & 0.0764 & 0.0574 & 0.0891 & 0.0764 & 0.0558 \\ 39 & 0.0869 & 0.0760 & 0.0570 & 0.0888 & 0.0760 & 0.0553 \\ 40 & 0.0866 & 0.0756 & 0.0565 & 0.0885 & 0.0756 & 0.0548 \\ 41 & 0.0863 & 0.0752 & 0.0560 & 0.0882 & 0.0752 & 0.0543 \\ 42 & 0.0859 & 0.0748 & 0.0555 & 0.0879 & 0.0748 & 0.0537 \\ 43 & 0.0856 & 0.0744 & 0.0550 & 0.0876 & 0.0744 & 0.0532 \\ 44 & 0.0853 & 0.0739 & 0.0545 & 0.0873 & 0.0739 & 0.0526 \\ 45 & 0.0849 & 0.0735 & 0.0539 & 0.0870 & 0.0735 & 0.0520 \\ 46 & 0.0845 & 0.0730 & 0.0533 & 0.0866 & 0.0730 & 0.0514 \\ 47 & 0.0841 & 0.0725 & 0.0527 & 0.0863 & 0.0725 & 0.0508 \\ 48 & 0.0833 & 0.0716 & 0.0516 & 0.0860 & 0.0723 & 0.0503 \\ 49 & 0.0825 & 0.0706 & 0.0506 & 0.0854 & 0.0714 & 0.0491 \\ 50 & 0.0816 & 0.0696 & 0.0495 & 0.0851 & 0.0711 & 0.0487 \\ 51 & 0.0806 & 0.0686 & 0.0483 & 0.0844 & 0.0702 & 0.0475 \\ 52 & 0.0797 & 0.0675 & 0.0471 & 0.0842 & 0.0700 & 0.0472 \\ 53 & 0.0786 & 0.0664 & 0.0458 & 0.0835 & 0.0691 & 0.0458 \\ 54 & 0.0780 & 0.0658 & 0.0449 & 0.0835 & 0.0693 & 0.0460 \\ 55 & 0.0773 & 0.0651 & 0.0429 & 0.0829 & 0.0686 & 0.0451 \\ 56 & 0.0766 & 0.0643 & 0.0419 & 0.0829 & 0.0688 & 0.0452 \\ 57 & 0.0759 & 0.0636 & 0.0408 & 0.0823 & 0.0681 & 0.0442 \\ 58 & 0.0751 & 0.0627 & 0.0397 & 0.0822 & 0.0683 & 0.0443 \\ 59 & 0.0742 & 0.0619 & 0.0385 & 0.0815 & 0.0675 & 0.0432\end{array}$




$\begin{array}{lllllll}60 & 0.0733 & 0.0610 & 0.0372 & 0.0814 & 0.0676 & 0.0432 \\ 61 & 0.0719 & 0.0595 & 0.0350 & 0.0803 & 0.0663 & 0.0413 \\ 62 & 0.0691 & 0.0563 & 0.0303 & 0.0788 & 0.0645 & 0.0384 \\ 63 & 0.0661 & 0.0528 & 0.0253 & 0.0764 & 0.0616 & 0.0339 \\ 64 & 0.0626 & 0.0490 & 0.0198 & 0.0746 & 0.0594 & 0.0307\end{array}$

Net Social Security Marginal Tax Rates

Marginal PIA/AIME: $\quad 0.15$

MTR on retirement income: 0.33

RETIRE AT NRA RETIRE AT 70

AGE MALE FEMALE ONE-EARNER MALE FEMALE ONE-EARNER

$\begin{array}{lllllll}21 & 0.0938 & 0.0849 & 0.0623 & 0.0948 & 0.0848 & 0.0609 \\ 22 & 0.0936 & 0.0847 & 0.0625 & 0.0946 & 0.0846 & 0.0612 \\ 23 & 0.0934 & 0.0844 & 0.0628 & 0.0944 & 0.0843 & 0.0614 \\ 24 & 0.0932 & 0.0841 & 0.0631 & 0.0942 & 0.0840 & 0.0617 \\ 25 & 0.0930 & 0.0838 & 0.0635 & 0.0940 & 0.0837 & 0.0621 \\ 26 & 0.0927 & 0.0835 & 0.0638 & 0.0938 & 0.0834 & 0.0624 \\ 27 & 0.0925 & 0.0832 & 0.0642 & 0.0936 & 0.0831 & 0.0628 \\ 28 & 0.0923 & 0.0829 & 0.0646 & 0.0934 & 0.0828 & 0.0631 \\ 29 & 0.0921 & 0.0826 & 0.0646 & 0.0932 & 0.0825 & 0.0631 \\ 30 & 0.0918 & 0.0823 & 0.0645 & 0.0930 & 0.0822 & 0.0630 \\ 31 & 0.0913 & 0.0816 & 0.0639 & 0.0925 & 0.0815 & 0.0623 \\ 32 & 0.0907 & 0.0810 & 0.0633 & 0.0921 & 0.0809 & 0.0616 \\ 33 & 0.0902 & 0.0803 & 0.0627 & 0.0917 & 0.0802 & 0.0608 \\ 34 & 0.0896 & 0.0796 & 0.0620 & 0.0912 & 0.0796 & 0.0600 \\ 35 & 0.0891 & 0.0789 & 0.0613 & 0.0907 & 0.0789 & 0.0592 \\ 36 & 0.0885 & 0.0782 & 0.0606 & 0.0903 & 0.0782 & 0.0583 \\ 37 & 0.0882 & 0.0778 & 0.0602 & 0.0900 & 0.0778 & 0.0578 \\ 38 & 0.0879 & 0.0775 & 0.0590 & 0.0898 & 0.0775 & 0.0574 \\ 39 & 0.0876 & 0.0771 & 0.0586 & 0.0895 & 0.0771 & 0.0569 \\ 40 & 0.0873 & 0.0767 & 0.0581 & 0.0892 & 0.0767 & 0.0564 \\ 41 & 0.0870 & 0.0763 & 0.0576 & 0.0889 & 0.0763 & 0.0559 \\ 42 & 0.0867 & 0.0759 & 0.0572 & 0.0886 & 0.0759 & 0.0554 \\ 43 & 0.0864 & 0.0755 & 0.0566 & 0.0883 & 0.0755 & 0.0549 \\ 44 & 0.0860 & 0.0750 & 0.0561 & 0.0880 & 0.0750 & 0.0543 \\ 45 & 0.0857 & 0.0746 & 0.0556 & 0.0877 & 0.0746 & 0.0538 \\ 46 & 0.0853 & 0.0741 & 0.0550 & 0.0874 & 0.0742 & 0.0532 \\ 47 & 0.0849 & 0.0737 & 0.0545 & 0.0870 & 0.0737 & 0.0526 \\ 48 & 0.0841 & 0.0728 & 0.0534 & 0.0868 & 0.0734 & 0.0521 \\ 49 & 0.0833 & 0.0718 & 0.0523 & 0.0861 & 0.0726 & 0.0509 \\ 50 & 0.0825 & 0.0709 & 0.0513 & 0.0859 & 0.0723 & 0.0506 \\ 51 & 0.0815 & 0.0699 & 0.0502 & 0.0852 & 0.0714 & 0.0494 \\ 52 & 0.0806 & 0.0688 & 0.0490 & 0.0850 & 0.0713 & 0.0490 \\ 53 & 0.0796 & 0.0677 & 0.0477 & 0.0843 & 0.0703 & 0.0477\end{array}$




$\begin{array}{lllllll}54 & 0.0790 & 0.0671 & 0.0469 & 0.0843 & 0.0705 & 0.0479 \\ 55 & 0.0783 & 0.0664 & 0.0449 & 0.0838 & 0.0699 & 0.0470 \\ 56 & 0.0777 & 0.0657 & 0.0439 & 0.0838 & 0.0701 & 0.0472 \\ 57 & 0.0769 & 0.0650 & 0.0429 & 0.0832 & 0.0694 & 0.0462 \\ 58 & 0.0762 & 0.0642 & 0.0418 & 0.0831 & 0.0695 & 0.0463 \\ 59 & 0.0753 & 0.0633 & 0.0406 & 0.0824 & 0.0688 & 0.0452 \\ 60 & 0.0744 & 0.0625 & 0.0393 & 0.0823 & 0.0689 & 0.0452 \\ 61 & 0.0730 & 0.0610 & 0.0372 & 0.0812 & 0.0676 & 0.0433 \\ 62 & 0.0704 & 0.0579 & 0.0327 & 0.0798 & 0.0659 & 0.0406 \\ 63 & 0.0674 & 0.0546 & 0.0278 & 0.0775 & 0.0630 & 0.0362 \\ 64 & 0.0641 & 0.0509 & 0.0224 & 0.0757 & 0.0610 & 0.0330\end{array}$

